\title{
TECHNOLOGY DEVELOPMENT FOR IRON FISCHER-TROPSCH CATALYSTS
}

\section{Contract DE-AC22-90PC90055}

\section{Technical Progress Report No. 5 9/26/91 - 12/26/91}

by

R. R. Frame and H. B. Gala

UOP

Des Plaines, Illinois

\section{DISCLAIMER}

This report was prepared as an account of work sponsored by an agency of the United States Government. Neither the United States Government nor any agency thereof, nor any of their employees, makes any warranty, express or implied, or assumes any legal liability or responsibility for the accuracy, completeness, or usefulness of any information, apparatus, product, or process disclosed, or represents that its use would not infringe privately owned rights. Reference herein to any specific commercial product, process, or service by trade name, trademark, manufacturer, or otherwise does not necessarily constitute or imply its endorsement, recommendation, or favoring by the United States Government or any agency thereof. The views and opinions of authors expressed herein do not necessarily state or reflect those of the United States Government or any agency thereof.

PATENT CIRARED EY CHIGAGO

OPC ON Octuber 20,1992 


\section{TECHNOLOGY DEVELOPMENT FOR IRON \\ FISCHER-TROPSCH CATALYSTS}

Contract DE-AC22-90PC90055

Technical Progress Report No. 5

$9 / 26 / 91 \cdot 12 / 26 / 91$

by

Robert R. Frame and Hemant B. Galn

UOP

25 E. Algonquin Road

Des Plaines, Illinols

\section{CONTRACT OBJECTIVE}

The objectives of this contract are to develop a technology for the production of active and stable iron Fischer-Tropsch catalysts for use in slurry-phase synthesis reactors and to develop a scaleup procedure for large-scale synthesis of such catalysts for process development and long-term testing in slurry bubble-column reactors. With a feed containing $\mathrm{H}_{2}$ and $\mathrm{CO}$ in the molar ratio of 0.5 to 1.0 to the slurry bubble-column reactor, the catalyst performance target is $88 \% \mathrm{CO}+\mathrm{H}_{2}$ conversion at a minimum space velocity of $2.4 \mathrm{NL} / \mathrm{hr} / \mathrm{gFe}$. The desired sum of methane and ethane selectivities is no more than $4 \%$, and the conversion loss per week is not to exceed $1 \%$.

\section{CONTRACT TASKS}

Task 1.0: Catalyst development

1.1: Technology assessment

1.2: Precipitated catalyst preparation method development

1.3: Novel catalyst preparation methods investigation

1.4: Catalyst pretreatment

1.5: Catalyst characterization

Task 2.0: Catalyst testing

Task 3.0: Catalyst aging studies

Task 4.0: Preliminary design and cost estimate of a catalyst synthesis facility 
SCOPE OF WORK DURING THE REPORTING PERIOD

\section{Tnsk 13}

Work is under way to prepare novel iron catalysts from calates. The preparation method developed can be modified to prepare iron metal catalyst, iron oxide catalyst precursors, and iron carbide catalysts. The method consists of micing iron (II) acetate with minor amounts of copper (II) and potassium acetates (see Appendix A). To this mixture is added sufficient methanol and water (5:1 by volume) to bring about solution, and then a alight ercess of walic acid is added. The resulting precipitate is recovered by filtration. Scanning electron microscopy of the precipitate indicates an intimate mixture of the coalates. Evidence indicates that vacuum heat treatment causes this material to lose mass in a stepwise fashion:

1. Surface-bound $\mathrm{H}_{2} \mathrm{O}\left(<100^{\circ} \mathrm{C}\right)$

2. Water of hydration (about $125^{\circ} \mathrm{C}$ )

3. Oxide(s) of carbon $\left(>200^{\circ} \mathrm{C}\right)$

Iron oxalate is known to thermally decompose to iron metal. The material prepared by the method described above is pyrophoric, and 20 the presence of zero valent metal is indicated.

\section{Tnsk 2.0}

A catalyst prepared by United Catalysts, Inc. (UCI) was evaluated in UOP's slurry autoclave plant. This catalyst was prepared as a prototype for a larger batch to be used in the alurry bubble-column reactor demonstration run at Air Product's LaPorte facility. This four-component catalyst contains $\mathrm{Fe}, \mathrm{Si}, \mathrm{Cu}$, and $\mathrm{K}$ in the following weight ratio: 100:8.06:4.38:8.58. The alurry autoclave reactor is operated inside a hot box, which is maintained at $160^{\circ} \mathrm{C}$. Feed is added continuousty below the liquid level in the reactor. Overhead gas is removed continuously from the reactor and taken first in a trap in the hot box $\left(160^{\circ} \mathrm{C}\right.$, about 5 psi less than the plant operating pressure) and then into a $0^{\circ} \mathrm{C}$ trap (50 psig) followed by a $-78^{\circ} \mathrm{C}$ trap (atmospheric pressure). A slipstream of the gas exiting the $160^{\circ} \mathrm{C}$ hot box is analyzed by an on-line GC analyzer, which performs a boiling-point type of analysis. A slipstream of the gas exiting the $0^{\circ} \mathrm{C}$ trap is analyzed by an on-line GC analyzer, which performs a gas analysis ( $\left.\mathrm{CO}, \mathrm{CO}_{2}, \mathrm{H}_{2}, \mathrm{~A}_{1} \mathrm{C}_{2}, \mathrm{C}_{2} \mathrm{C}_{3}\right)$. The liquid level in the 
autoclave is maintained at a constant level by periodic withdrawals of wax. This wax is also taken into the hot box trap; any material that does not condense in this trap is taken into the two traps that are outside the hot box.

A single run (Run 44) was performed with this catalyst. The catalyst testing procedure and conversion-selectivity calculations are described in the Technical Progress Report covering the period from $4 / 1 / 90$ to $6 / 30 / 90$ of a previous UOP Fischer-Tropsch contract, DE-AC2287PC79812.

\section{Bun 48}

The autoclave was loaded with $72.7 \mathrm{~g}$ of as-received UCI catalyst and $290 \mathrm{~g}$ of a C-30 oil obtained from the Ethyl Corporation.

The pretreatment was $12 \mathrm{hr}$ long. During this time, the normal feed, which is a blend of $\mathbf{H}_{2}$ $C O$, and $A$ in the molar ratio 0.7:1.0:0.1, was used. Argon is an internal standard. The feed rate, temperature, and pressure were $2 \mathrm{NL} / \mathrm{hr} / \mathrm{gFe}, 280^{\circ} \mathrm{C}$, and $153 \mathrm{psig}$, respectively. These conditions are the same as those used in all of UOP's recent work and are based on pretreatment conditions used by previous workers. During the remainder of the run, the feed rate, temperature, and pressure were $2.4 \mathrm{NL} / \mathrm{hr} / \mathrm{gFe}, 265^{\circ} \mathrm{C}$, and $290 \mathrm{psig}$ respectively.

Run 44 results are summarized in the figures and table in Appendix B. Figure 1 summarizes $\mathrm{CO}$ conversion. As was found with previous runs, the conversion fell rapidly right after the activation period and then fell more slowly. By about $400 \mathrm{hr}$ on-stream, the $\mathrm{CO}$ conversion appeared to stabilize at $60 \%$. Activity loss also occurred before apparent stabilization with UOP's three component catalyst ( $\mathrm{Fe}, \mathrm{Cu}, \mathrm{K}$ ). Figure 2 compares the $\mathrm{CO}, \mathrm{H}_{2}$ and $\mathrm{CO}+\mathrm{H}_{2}$ conversions along with the $\mathrm{H}_{2}$ and $\mathrm{CO}$ usage, which was constant throughout the run at 0.55 . Figure 3 contains a summary of $\mathrm{CO}_{2}$ selectivity, which was as high as expected for an iron-based catalyst.

A step down in activity was noted when a new feed (Feed B) was used. A small amount of the previous feed (Feed A) was available. When it was reintroduced, the catalyst activity seemed to recover somewhat; however, not enough of this feed was available to run long enough to definitely conclude that the activity loss with the second feed was fully reversible. Attempts were 
made to determine if the second feed had any impurities. Both feeds were analyzed for trace amounts of sulfur (total) and oxygen (Table 1); however, in both feeds, these elements were below the limits of the detectability of the analytical instruments.

The UCI catalyst was formulated to produce low levels of light ends. Figures 4, 5, and 6 summarize the $C_{1}$ to $C_{3}$ hydrocarbon selectivities from the on-line gas analysis. These selectivities are as low as expected. Near the end of the run, these selectivities appeared to be lining out; at that point, the sum of the $C_{1}$ and $C_{2}$ paraffin selectivities was $5.2 \%$.

Figures 7 to 13 summarize $C_{1}$ to $C_{10}$ selectivities as calculated from boiling point $G C$ analysis. Figure 14 is a plot of $\log$ mole fraction at a given carbon number vs. carbon number at $450 \mathrm{hr}$ onstream (Schulz-Flory plot). The plot was constructed from data in Figures 1 to 13. The data show an apparent linear relation up to $C_{6}$; past $C_{6}$ the curve appears to break away from linearity. The historic Schulz-Flory mechanism rationalizes Fischer-Tropsch product distribution using Flory's mathematical treatment of polymerization chemistry. A constant, alpha, is employed. This constant is the probability that a chain of a given length will grow by one carbon unit. A plot such as the one in Figure 14 is predicted to be linear for all carbon numbers; the slope of this plot should be $\log$ alpha. Satterfield and others have attributed deviations from linearity to a mechanism in which two alpha's are operative: alpha-1, which dominates at low carbon numbers, and alpha-2, which dominates at high carbon numbers. ${ }^{1}$ A double-alpha plot has apparently linear portions (actually asymptotic) at low and high carbon numbers and a curved portion connecting the two asymptotes. Satterfield developed a nonlinear regression method, which gives alpha-1 and alpha-2. He says values of alpha calculated from linear regression analysis of the asymptotic parts of the curve are within 5 to $10 \%$ of the nonlinear regression alpha's. Linear regression analysis of the data in Figure 14 provided a value for alpha of 0.69 .

The weight of products collected in the various traps is summarized in Table 2 and Figure 15. Not much material was in the hot-box trap for the first several periods, largely because the initial wax products were allowed to remain in the autoclave $s 0$ that the autoclave liquid level could build to the target level. Figure 15 contains a plot of autoclave liquid level vs. hours on-stream. The rate of wax production can be estimated by the weights collected in the hot box trap. Apparently, the wax production decreased slowly during the run, most likely because of the conversion loss. 


\section{CONCLUSIONS}

A mixed oxalate of iron, copper, and potassium was prepared. Characterization work has begun, and eventually, a catalyst will be prepared from this material, which may also be used to make pure iron carbides.

An evaluation run was performed on an iron-based UCI catalyst, which was prepared as a prototype for the LaPorte run scheduled for the summer of 1992 . This catalyst was designed to produce a low level of light ends, particularly $C_{1}$ and $C_{2}$ paraffins. UOP's test confirmed that the UCI catalyst produces low levels of $C_{1}$ and $C_{2}$ parafiins. For instance, at the end of the run, when the catalyst was converting $60 \%$ of the $C O$, the $C_{1}$ and $C_{2}$ paraffin selectivities were 4.2 and 1.0 , respectively.

\section{REFERENCE}

1. T. J. Donnelly, I. C. Yates, and C. N. Satterfield, Energy and Fuels, 1988, 2, 734-739. 
Bisure 1

\section{UCI CATALYST}

PLT $700 B$ RUN $44 \mathrm{H}_{2}: \mathrm{CO}$ foed $=0.7,9100 \mathrm{rpm}$

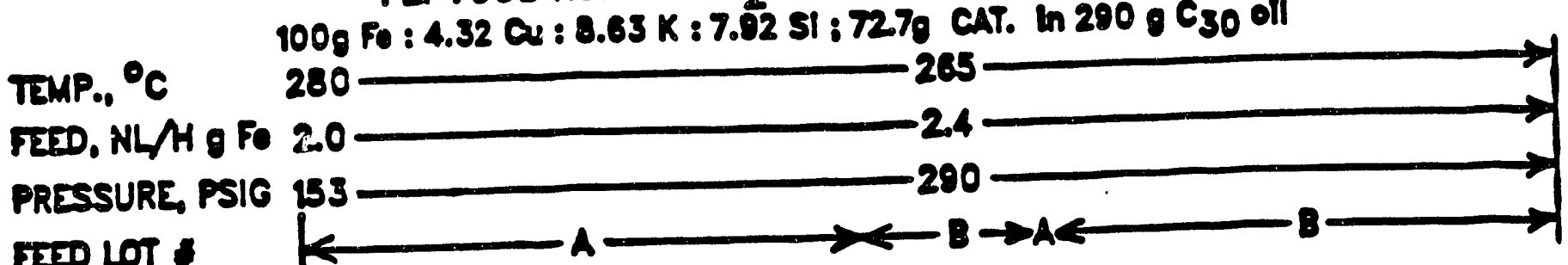

FED LOT

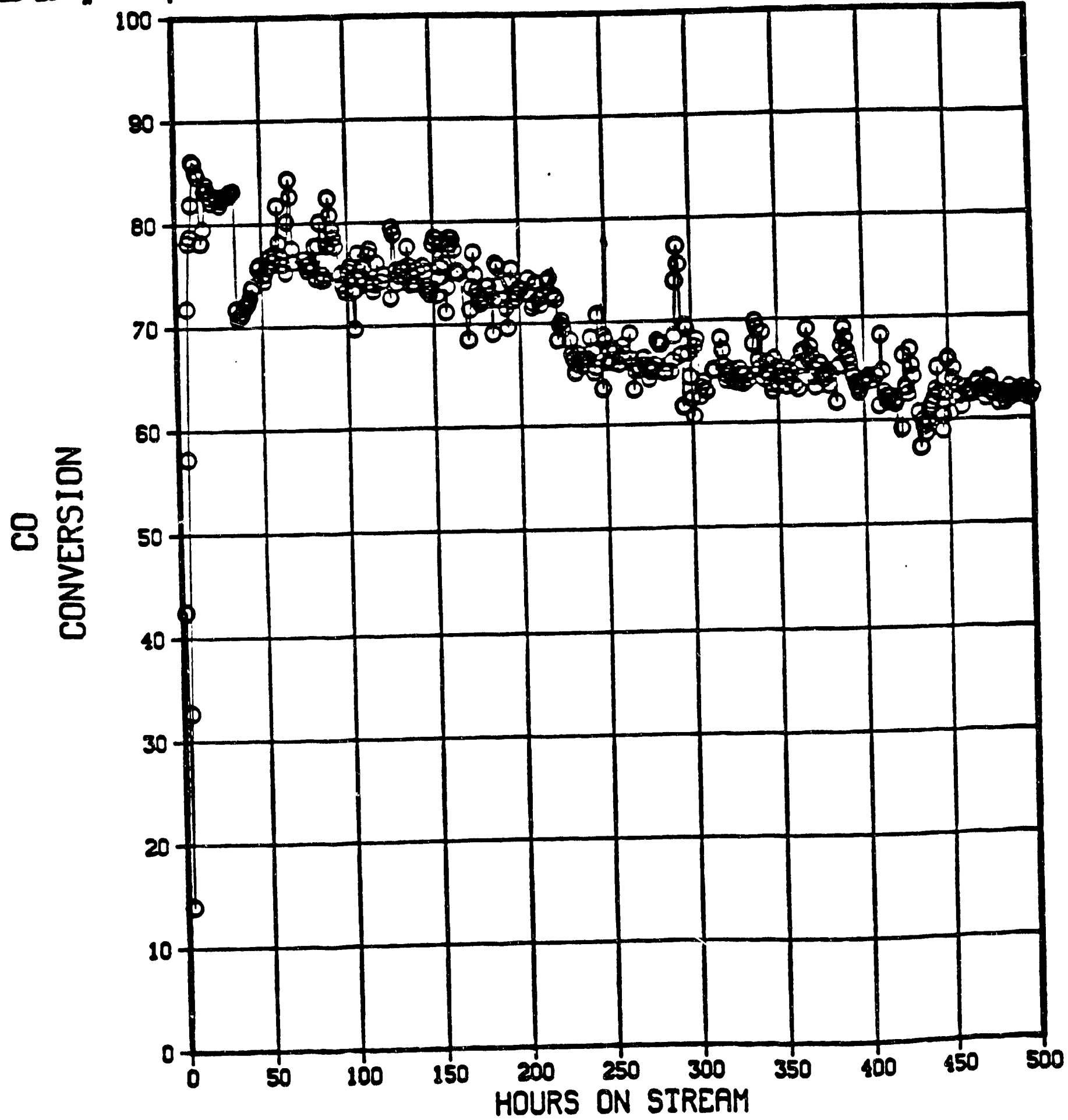




\section{UCI CATALYST}

PLT 700B RUN $44 \mathrm{H}_{2}: \mathrm{CO}$ foed $=0.7,1100 \mathrm{rpm}$

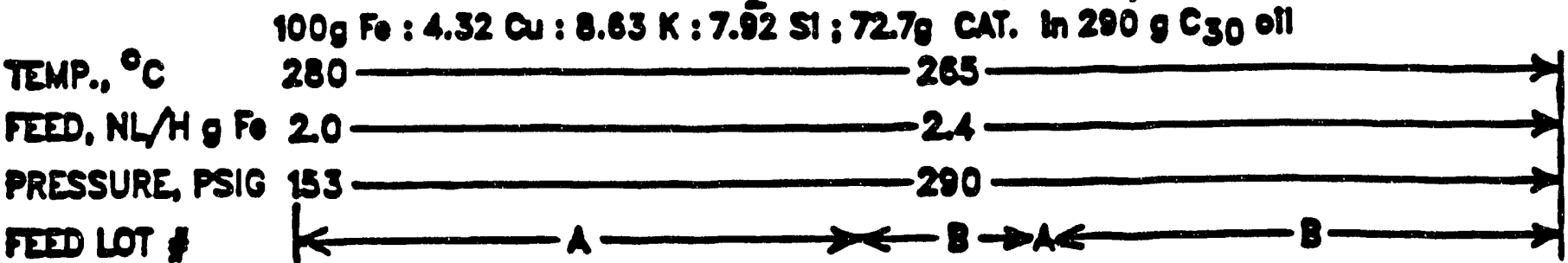
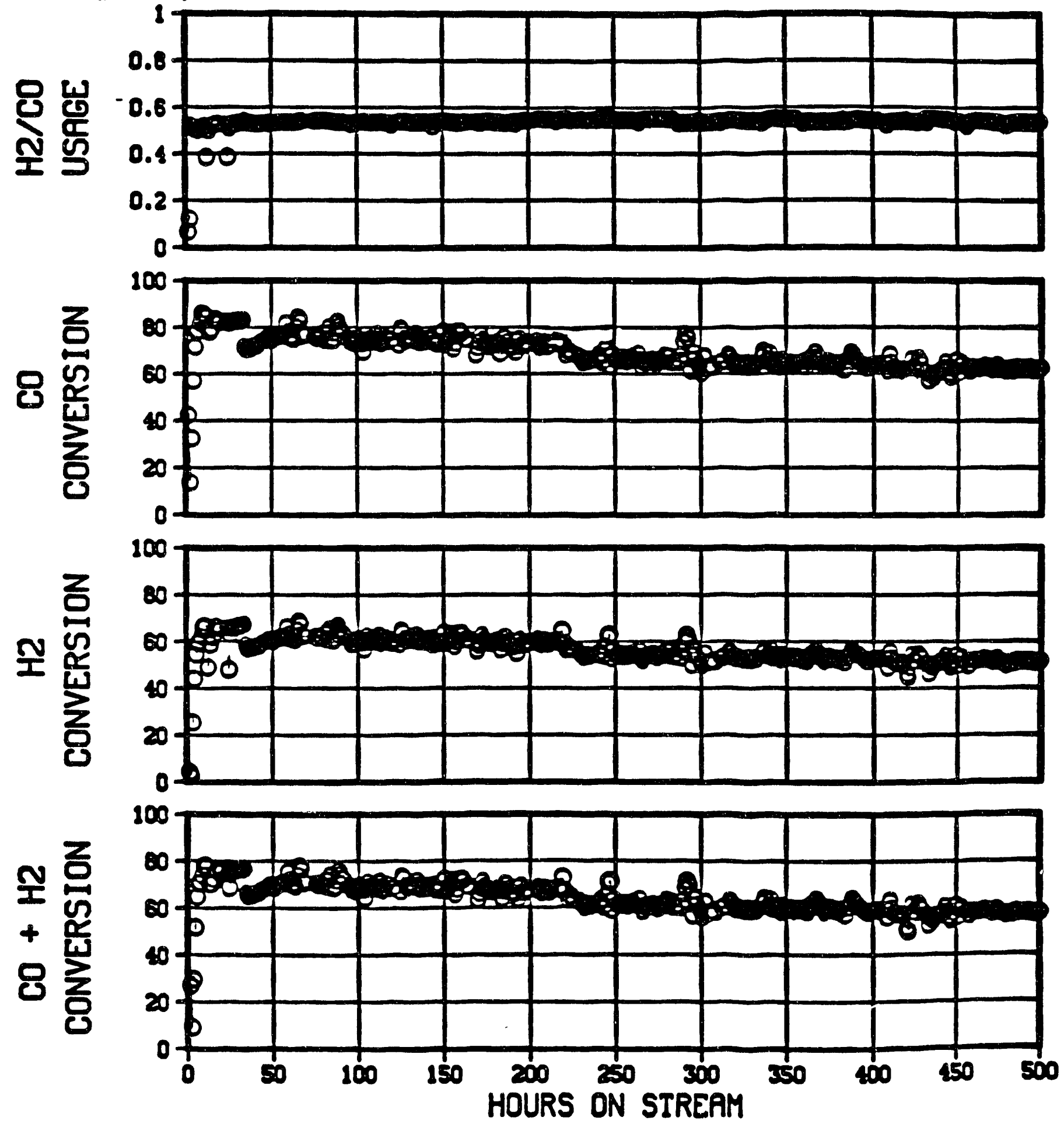
Pigure 3

\section{UCI CATALYST}

PLT 700B RUN $44 \quad \mathrm{H}_{2}: \mathrm{CO}$ foed $=0.7,1100 \mathrm{rpm}$ 100 Fo : 4.32 Ou : $8.63 \mathrm{~K}: 7.0251$; 72.79 CAT. In 290 o $C_{30}$ oll

TEMP., ${ }^{\circ} \mathrm{C} \quad 280$

FEED, NLAH O FO 20

PRESSURE, PSIG

मมD LO

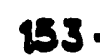

265

$-2.4$

$-290$

ช

L

A

$\rightarrow=8 \rightarrow 45$

B

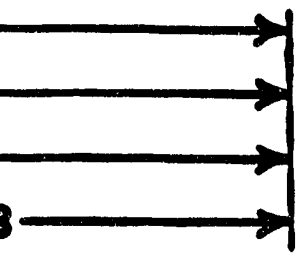

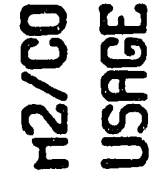

100

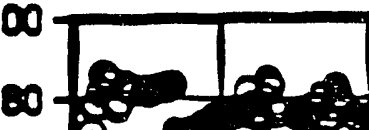

8

p

10

$\infty$

0

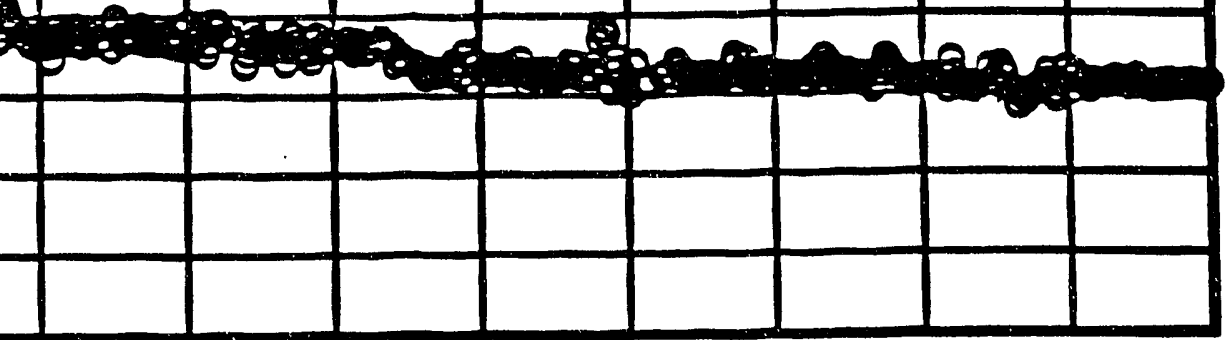

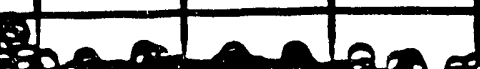

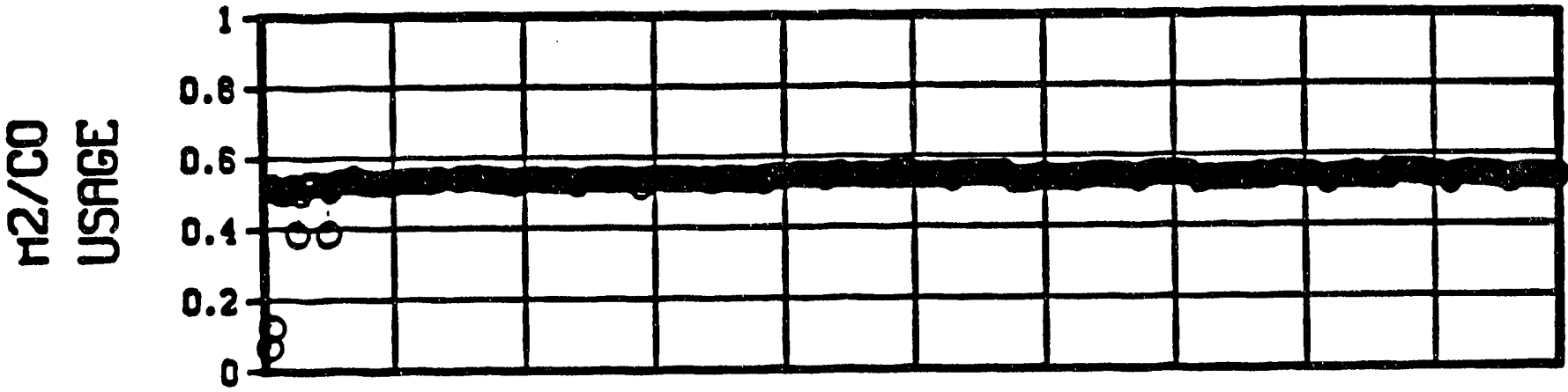

$5 \frac{5}{5}$

2.5

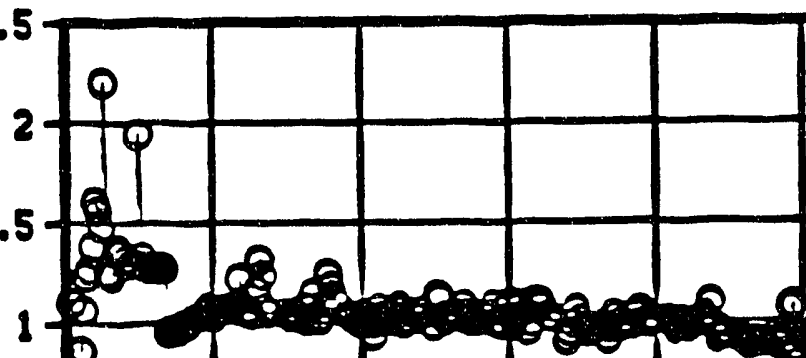

A
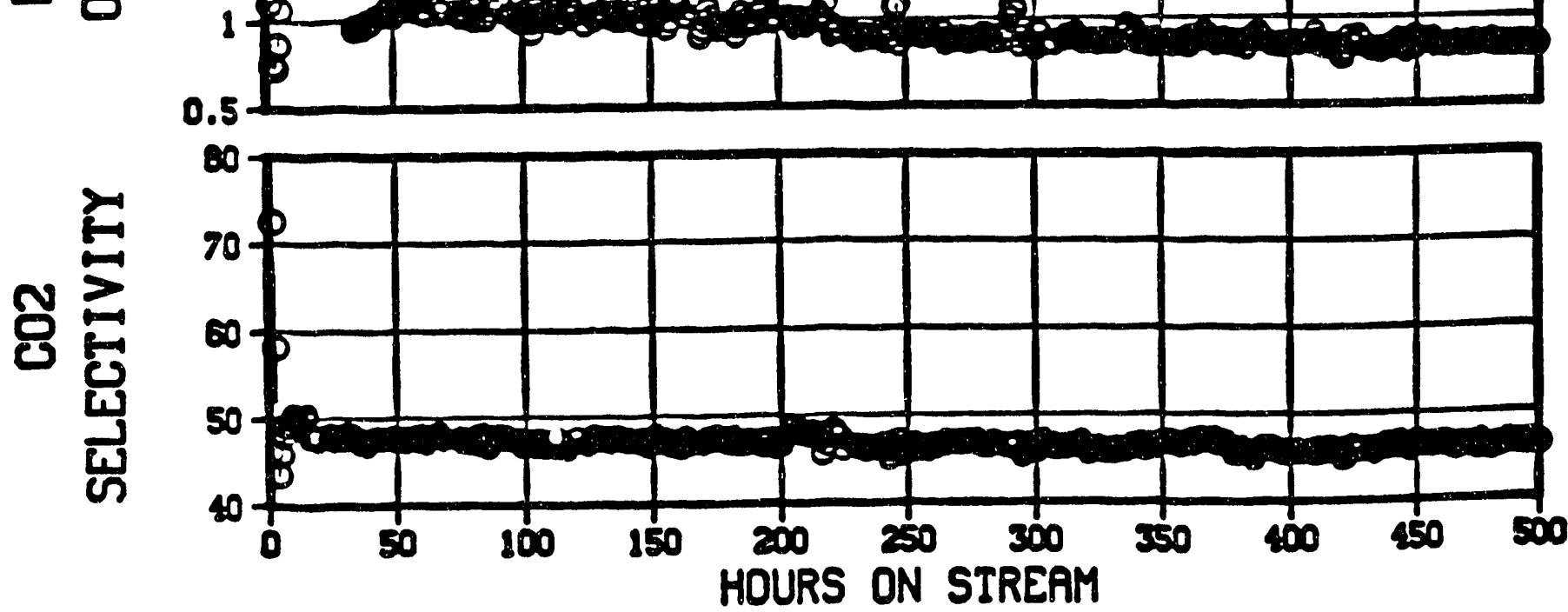
Pigure 4

\section{UCI CATALYST}

PLT 700B RUN $44 \mathrm{H}_{2}: \mathrm{CO}$ food $=0.7,1900 \mathrm{rpm}$

i.

TEMP., ${ }^{\circ} \mathrm{C} \quad 280$

FED, NL/H o FO 20

PRESSURE, PSIG 253

TED LOT

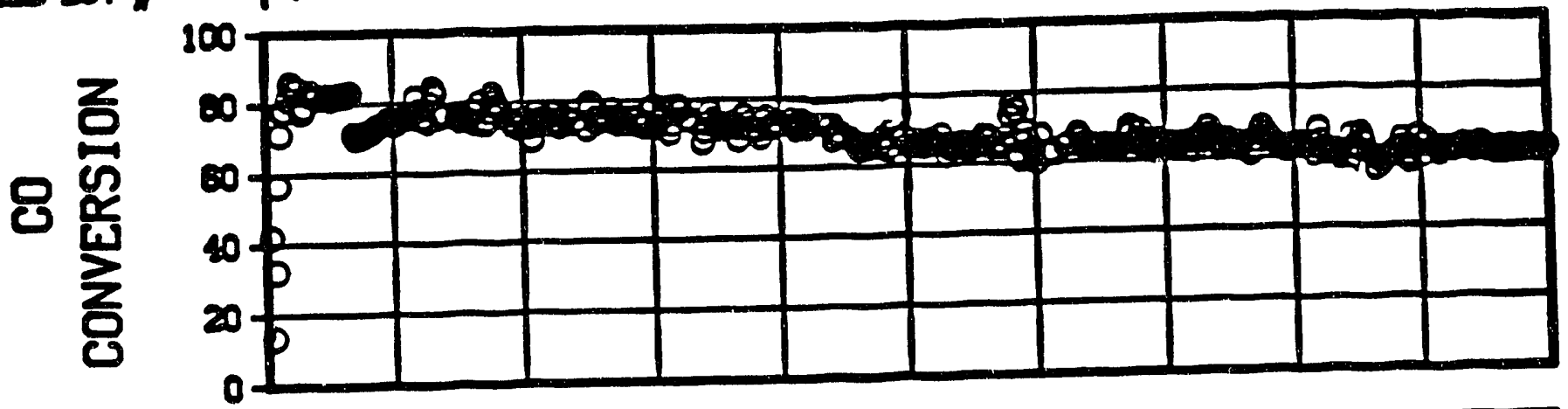

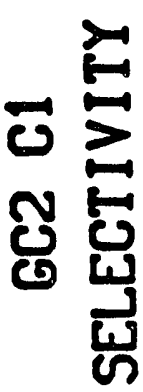

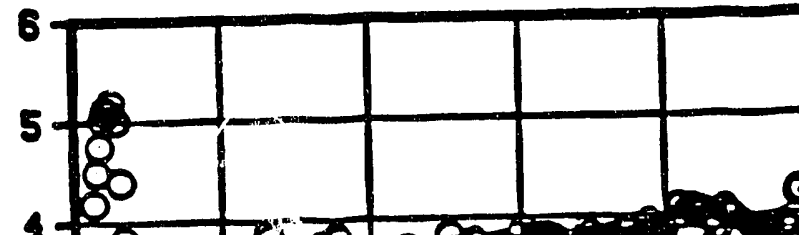

265

24

290

○ $C_{30}$ oll 
Pigure 5

\section{UCI CATALYST}

PLT 700B RUN $44 \mathrm{H}_{2}: \mathrm{CO}$ food $=0.7,1100 \mathrm{rpm}$

i

TEMP., ${ }^{\circ} \mathrm{C} \quad 280$

FED, NL/N o FO 2.0

PRESSURE, PSIG 253

FED LOT

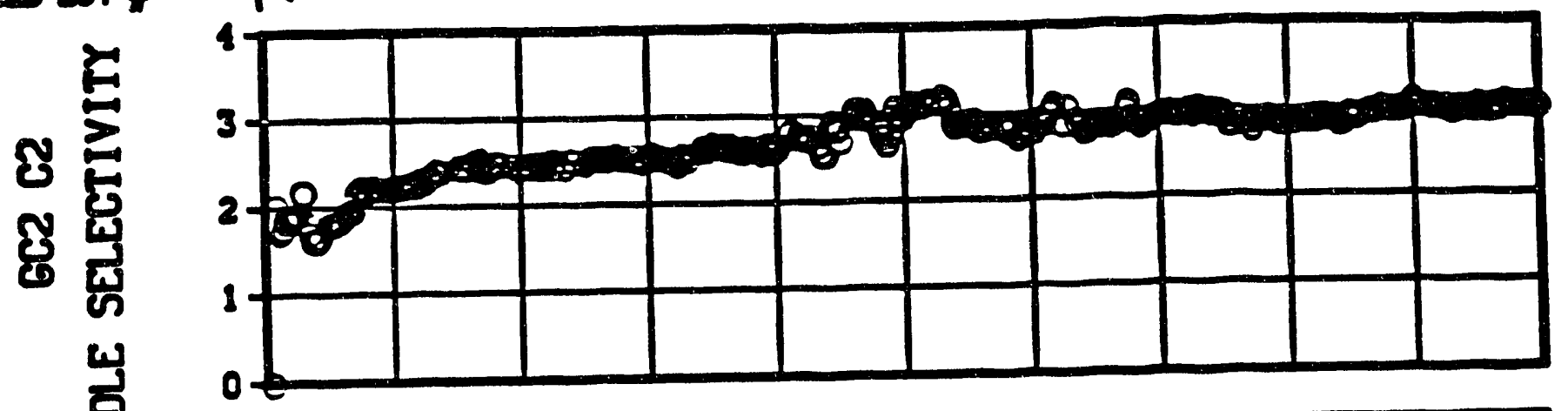

ช

2.5

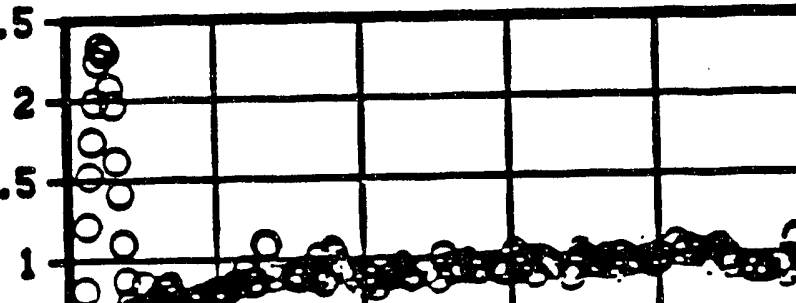

옹 봉

0.5

$\mathrm{FO}: 4.32 \mathrm{Cu}: 8.63 \mathrm{~K}: 7.02 \mathrm{S1}: 7270$ 
Pibure 6

UCI CATALYST

PLT 7008 RUN $44 H_{2}: C O$ food $=0.7,1100 \mathrm{rpm}$

100 g Fo : 4.32 O : $8.63 \mathrm{~K}: 7.0251$ : 72.79 CAT. in 200 o C 30 oll

FED, NLAH g Fo 20 - 2.4

PRESSURE, PSIG 253

290

FED LOT

$\leftarrow$ A

$B \rightarrow A$

B

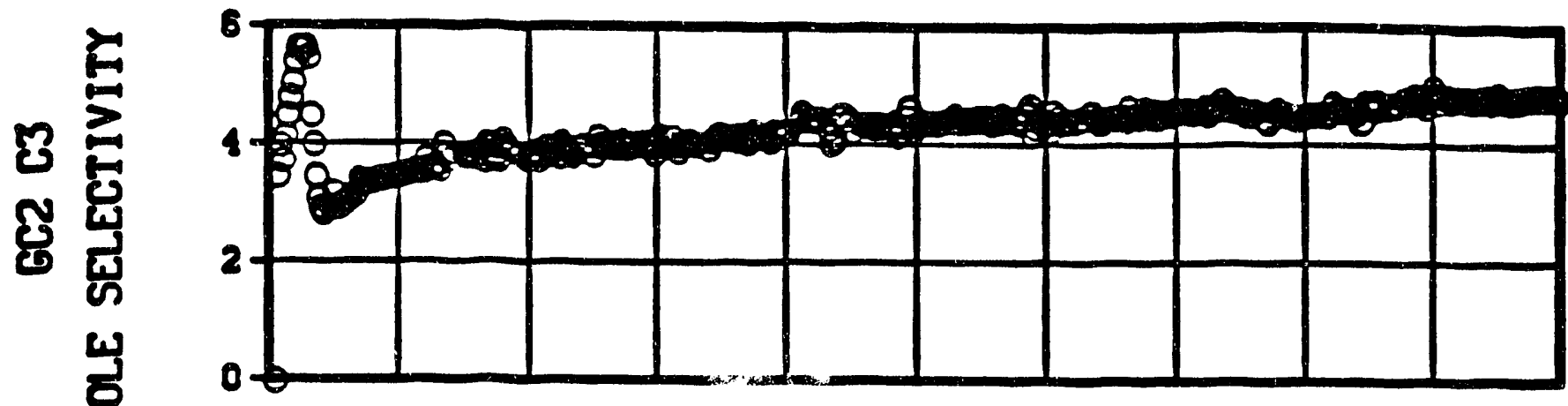

$3 \sum^{2}$

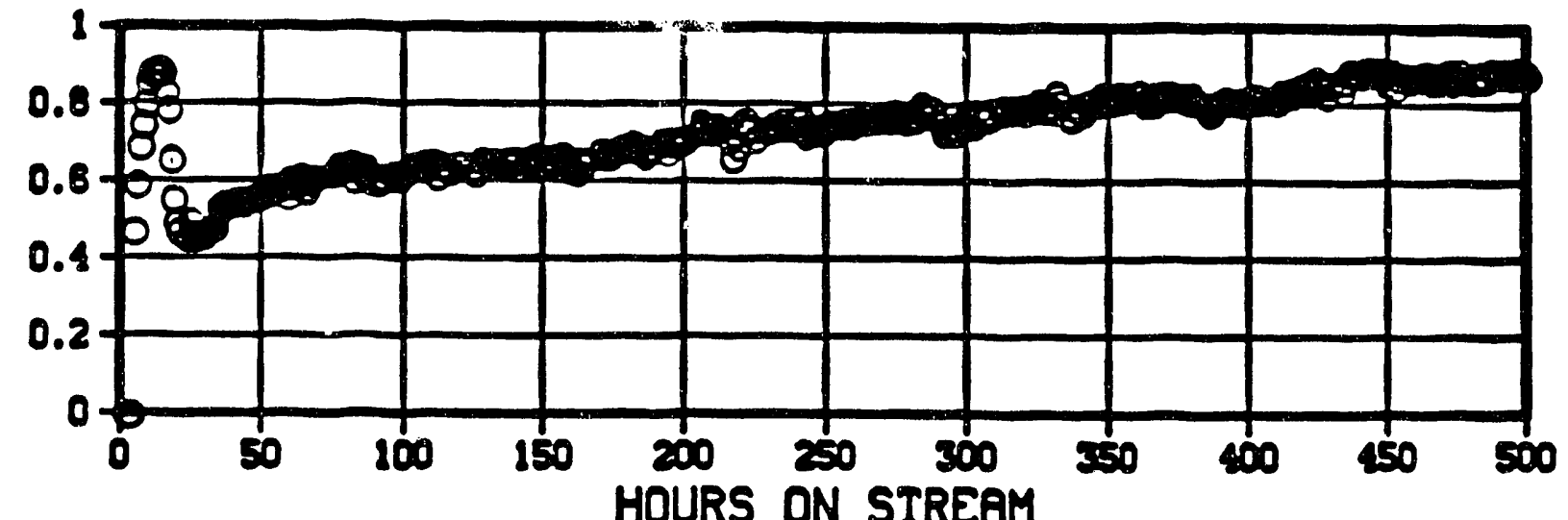


Nioure 7

\section{UCI CATALYST}

PLI 7008 RUN \&4 $\mathrm{H}_{2}: \mathrm{CO}$ \% $\bullet d=0.7,1100 \mathrm{rpm}$

C TEMP., ${ }^{\circ} \mathrm{C} \quad 280$ FEDD, NLAH O Fo 20 PRESSURE, PSIG 253 TयDO LOT K $A$ 265
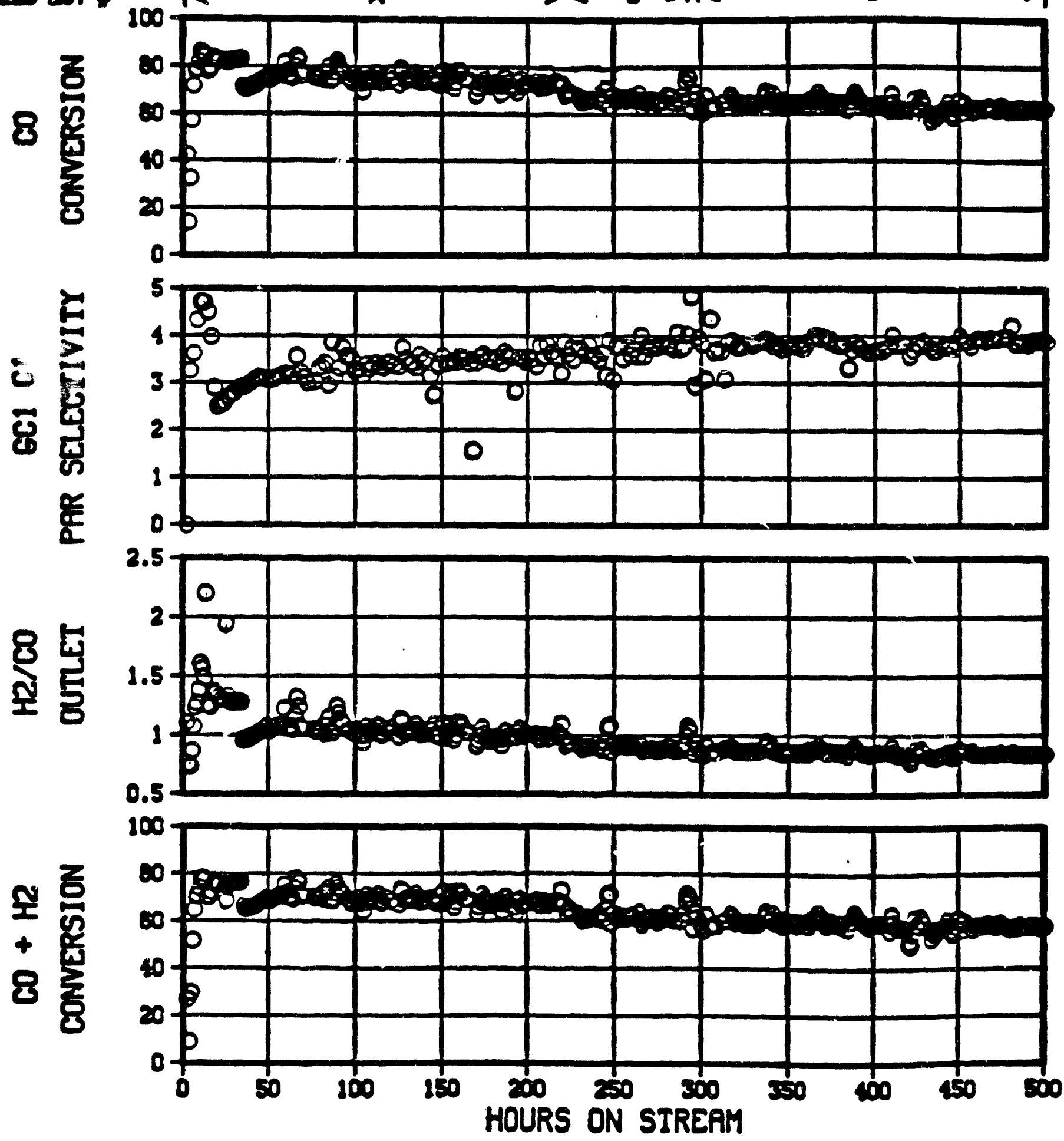


\section{TEMP.o ${ }^{\circ} \mathrm{C} \quad 280$}

PUD, NLAH O FO 20

PRESSURE, PSIO 253

TEDT LOT

L3- A

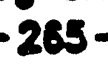

है

1.5 o
1.2 to
$0.8+5$

$0.8 \frac{60}{50}$

0.3

$\%$

0

- 0 of

24

290

$\longrightarrow \longrightarrow B \rightarrow A F$

8
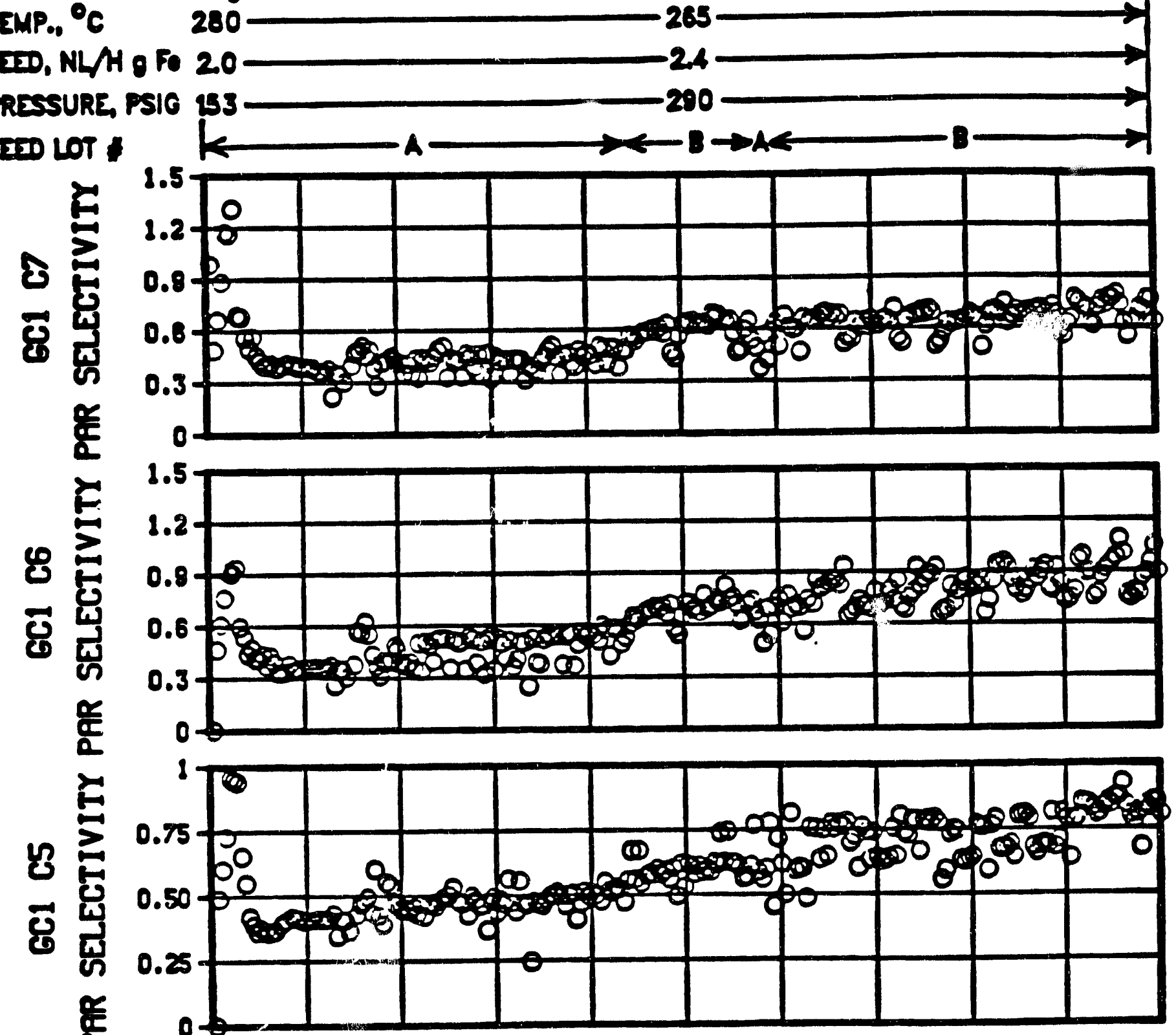

ฮ

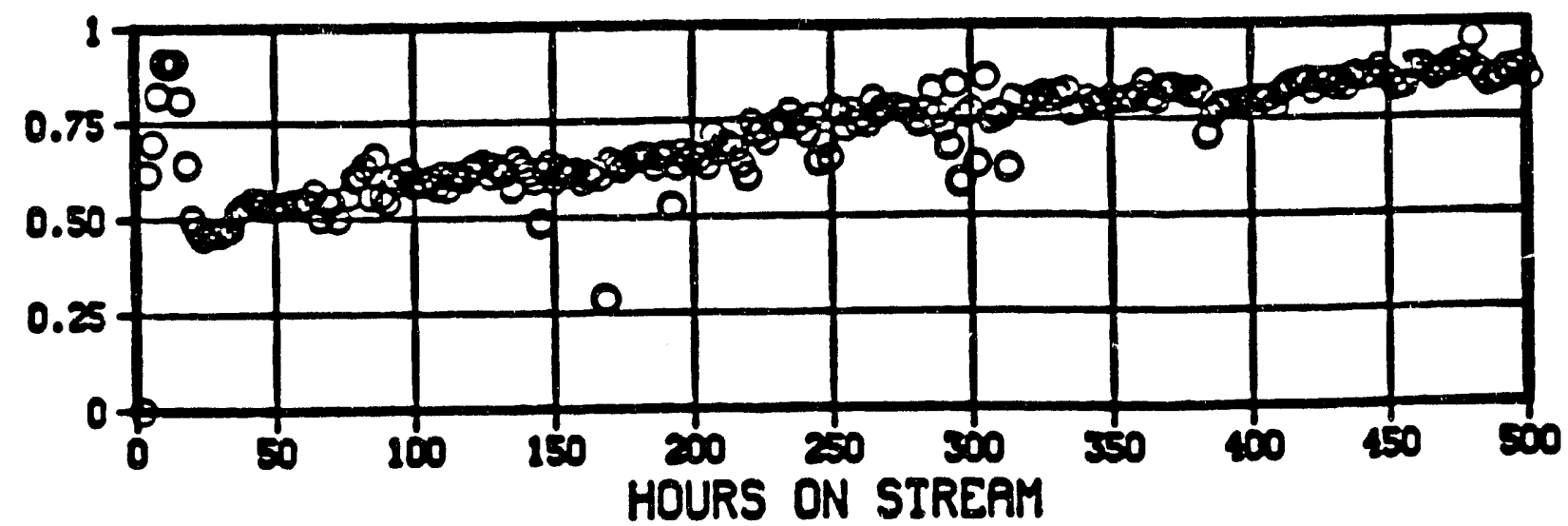


PLT 7008 RUN $44 \mathrm{H}_{2}: \mathrm{CO}$ food $=0.7,1100 \mathrm{rpm}$

( $100 \mathrm{~g} \mathrm{Fo}: 4.32$ Q : $8.63 \mathrm{~K}: 7.02 \mathrm{s1}: 72.7 \mathrm{~g}$ CAT. In $200, \mathrm{C}_{30}$ oll TEMP. ${ }^{\circ} \mathrm{C} 280$ FED, NLAH O FO 20 PRESSURE, PSIG

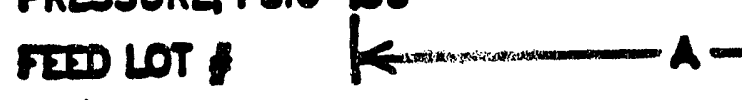

$$
\begin{aligned}
& 265 \\
& -24
\end{aligned}
$$$$
290
$$
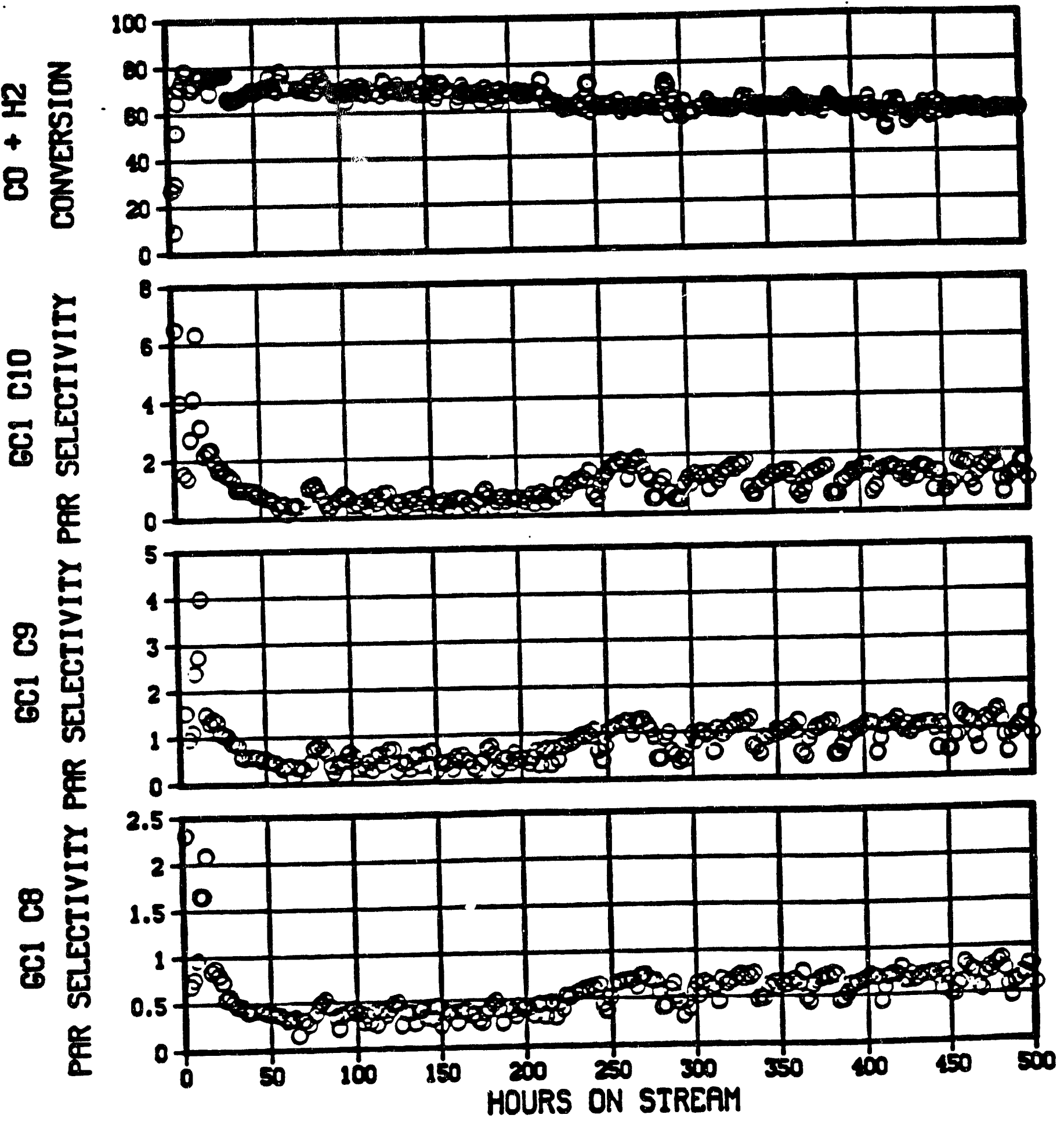
Pisure 10

\section{UCI CATALYST}

PLT 700B RUN 44 $\mathrm{H}_{2}: \mathrm{CO}$ foed $=0.7,1100 \mathrm{rpm}$ $100 \mathrm{~g}$ Fo : $4.32 \mathrm{Cu}: 8.63 \mathrm{~K}$ : $7.02 \mathrm{s1}$; 7279 CAT. In 200 g C30 oll

TEMP., ${ }^{\circ} \mathrm{C} \quad 280$

FEDD, NLAH O FO 2.0

PRESSURE, PSIG 253

กDD LOT

L

$$
\begin{aligned}
& 265 \\
& -24 \\
& -200
\end{aligned}
$$

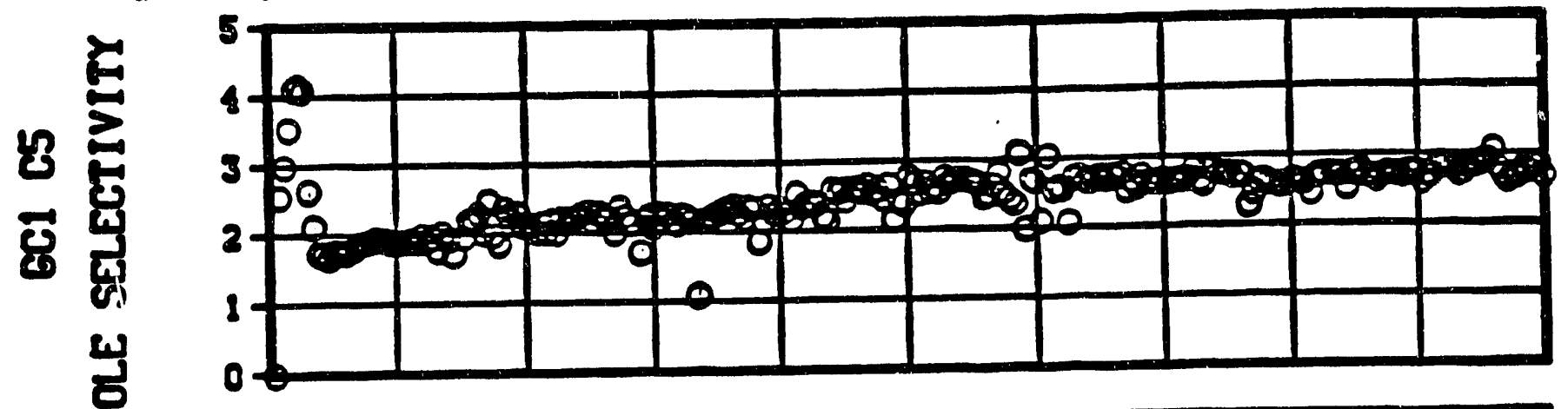

टै है

点

5

ध

(4)
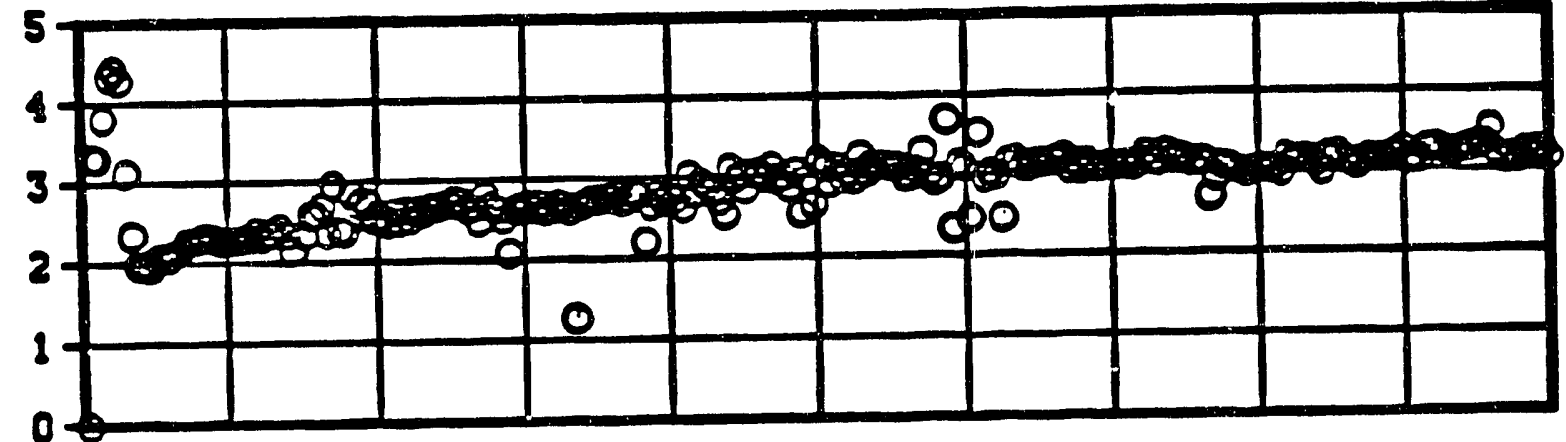

$$
67
$$

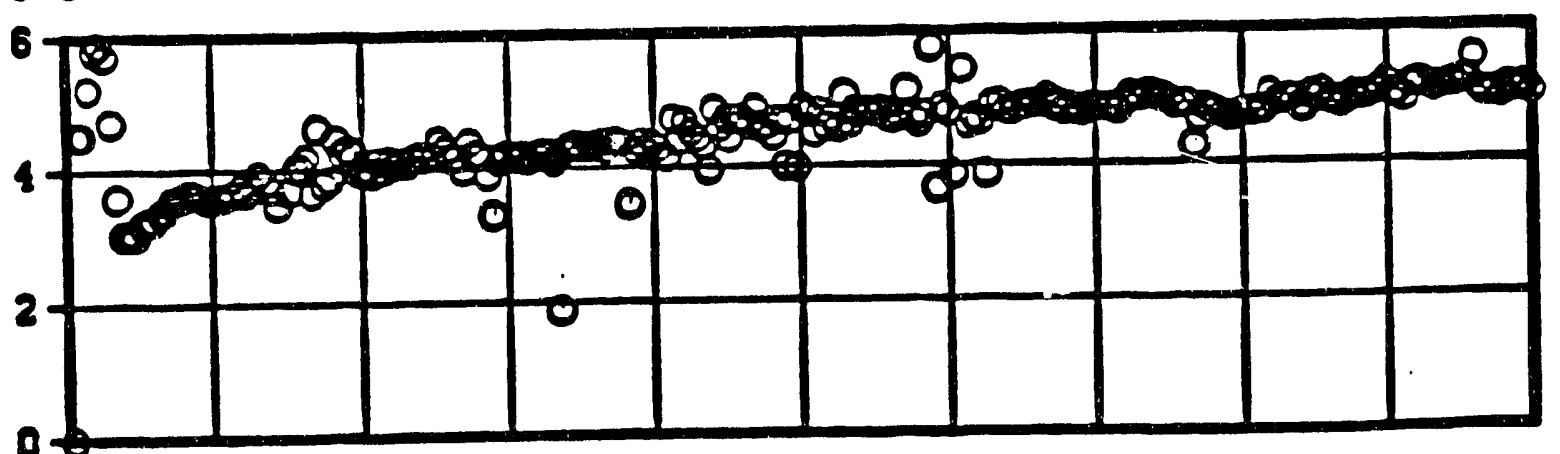

ช

넣

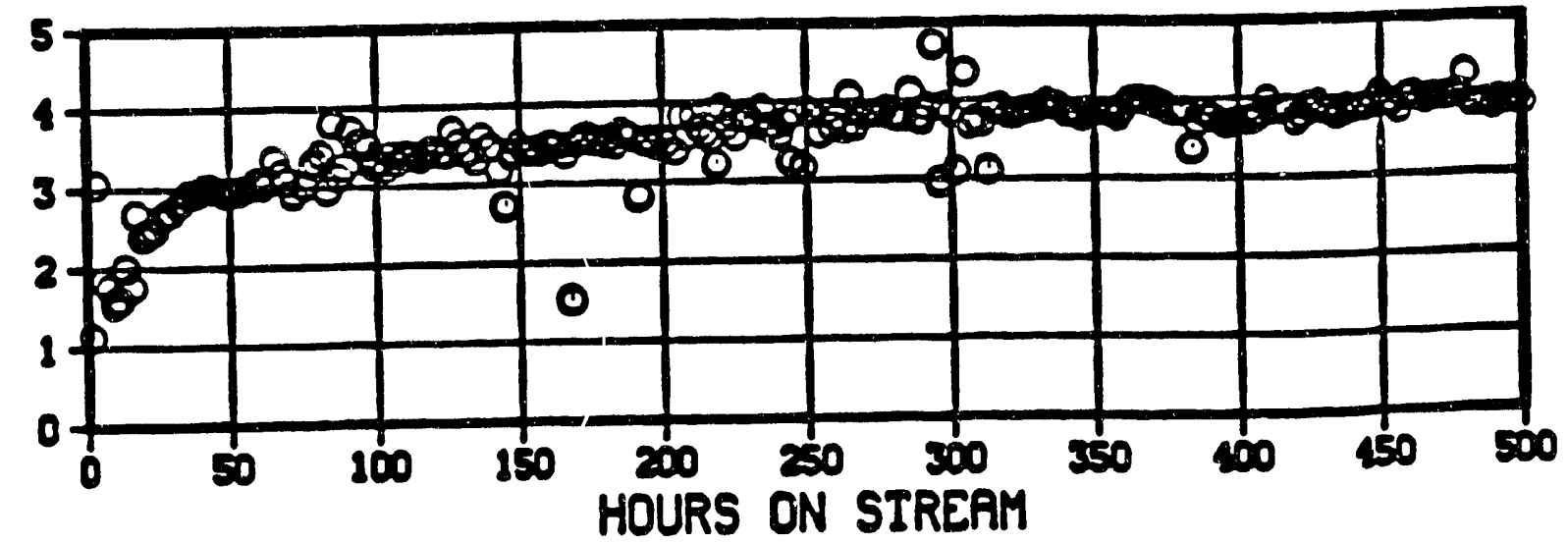


Pigure 11

UCI CATALYST

PLT 700B RUN $44 \mathrm{H}_{2}: \mathrm{CO}$ food $=0.7,1100 \mathrm{rpm}$ $100 \mathrm{~g} F \mathrm{~F}: 4.32$ Cu : $8.63 \mathrm{~K}: 7.02 \mathrm{~F}$ : $727 \%$ CAT. In 290 \& $\mathrm{C}_{30}$ oll
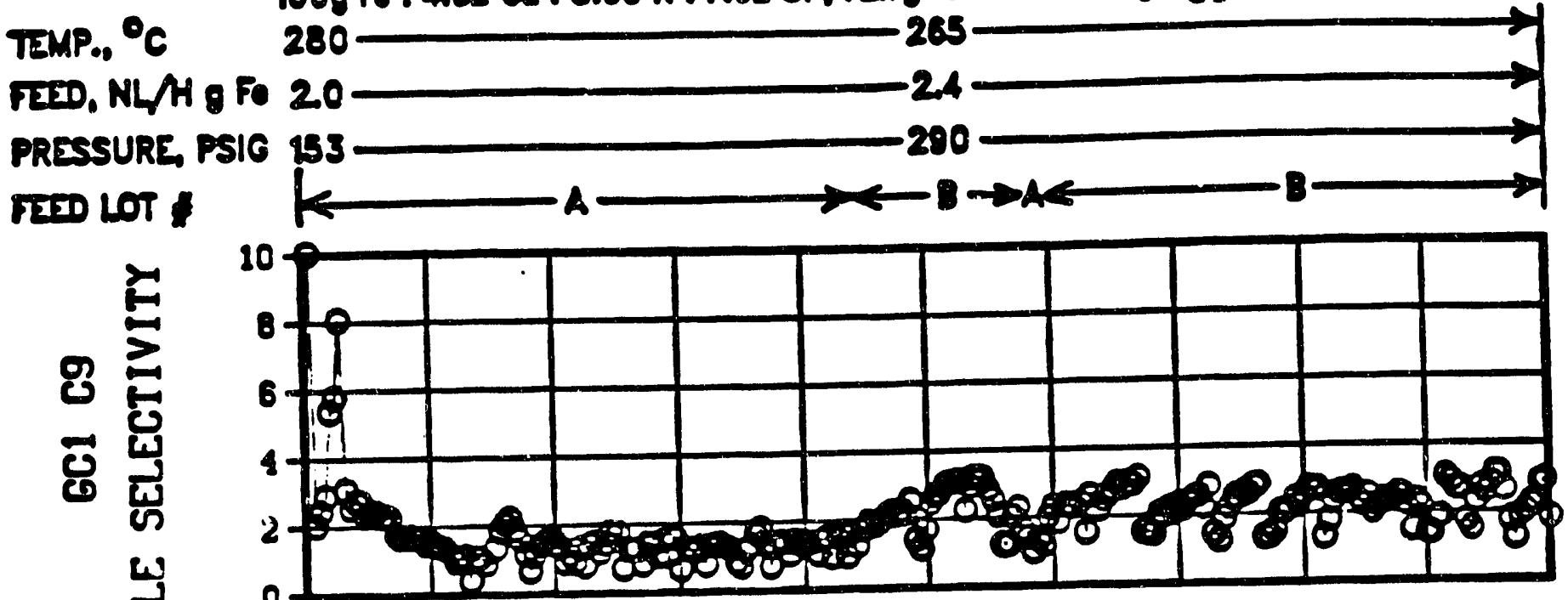

क 01

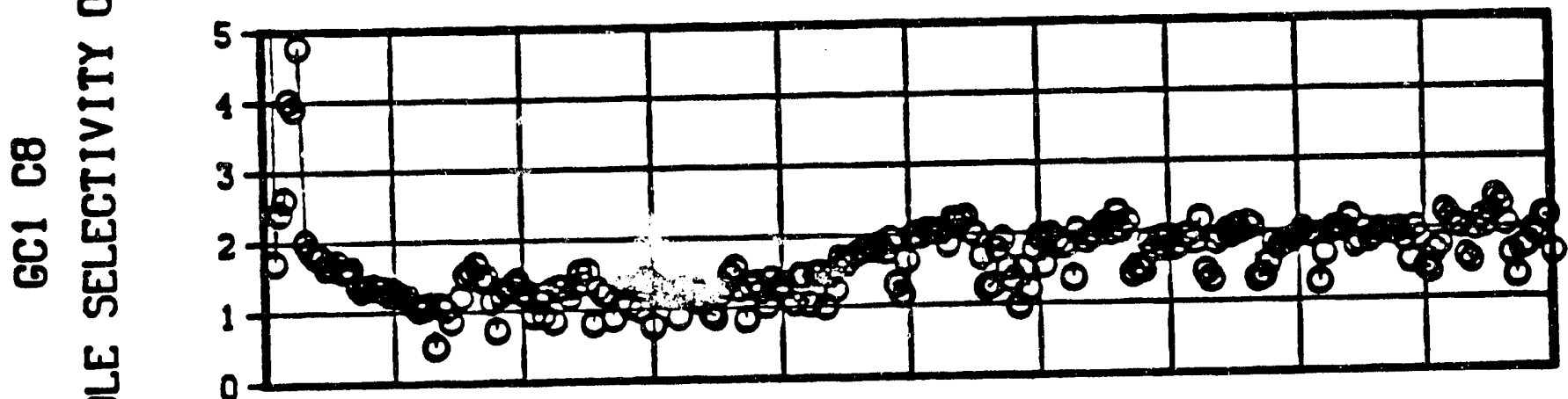

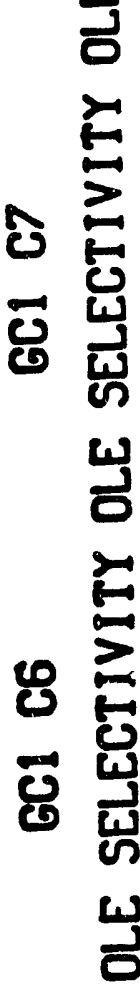

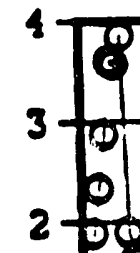

$1-$

岁

0

4

10

$3-\frac{1}{0}$
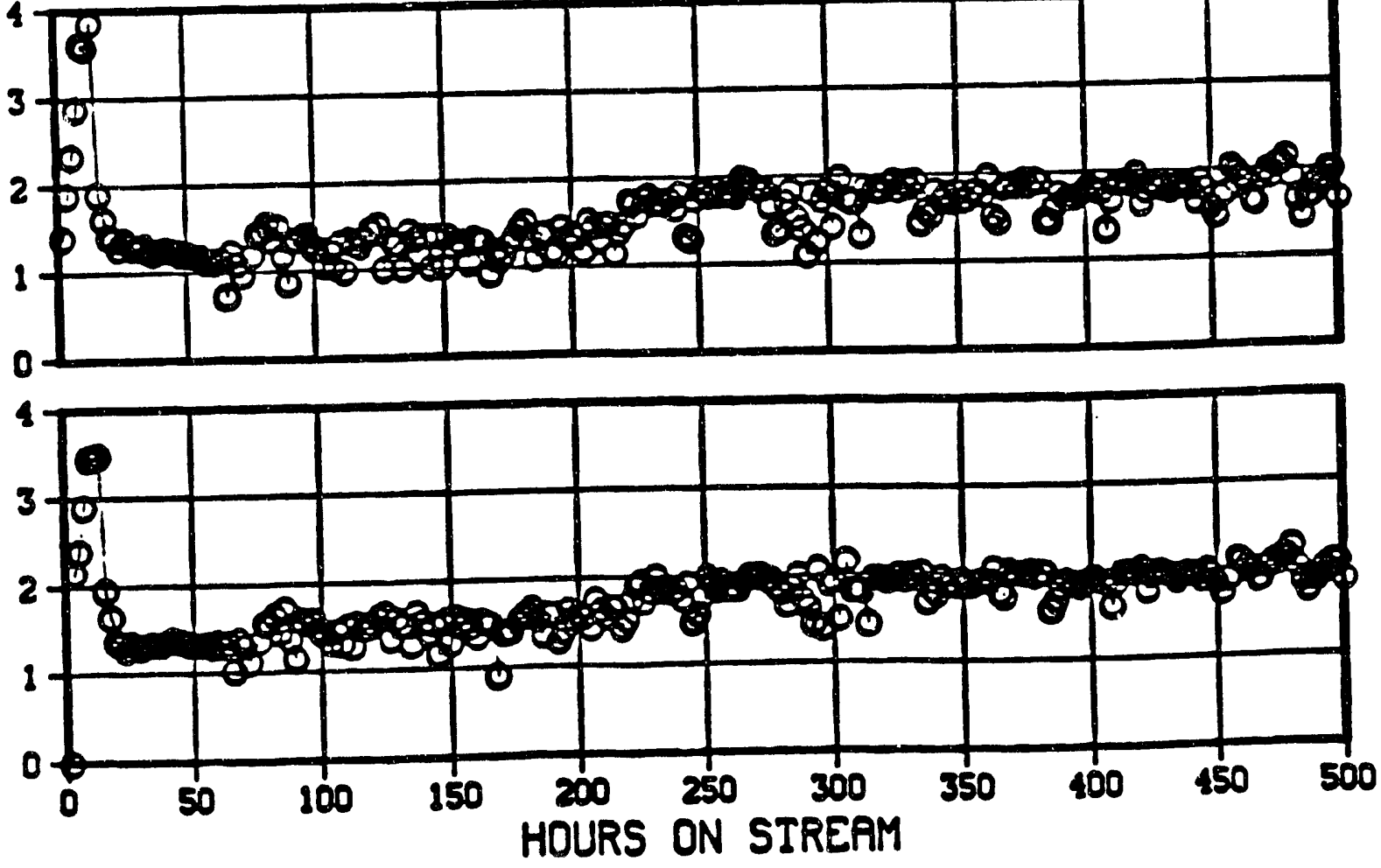
Pigure 12

UCI CATALYST

PLT 700B RUN $44 \mathrm{H}_{2}: \mathrm{CO}$ foed $=0.7,1100 \mathrm{rpm}$

( $00 \mathrm{~g}$ Fo : 4.32 Cu : $8.63 \mathrm{~K}: 7.02 \mathrm{s1}$ : 72.79 CAT. $\ln 290$ g C 30 oll TIMP.0 ${ }^{\circ} \mathrm{C} \quad 280$

FEDD, NLAH g FO 20

PRESSURE, PSIG 53

FID LOT

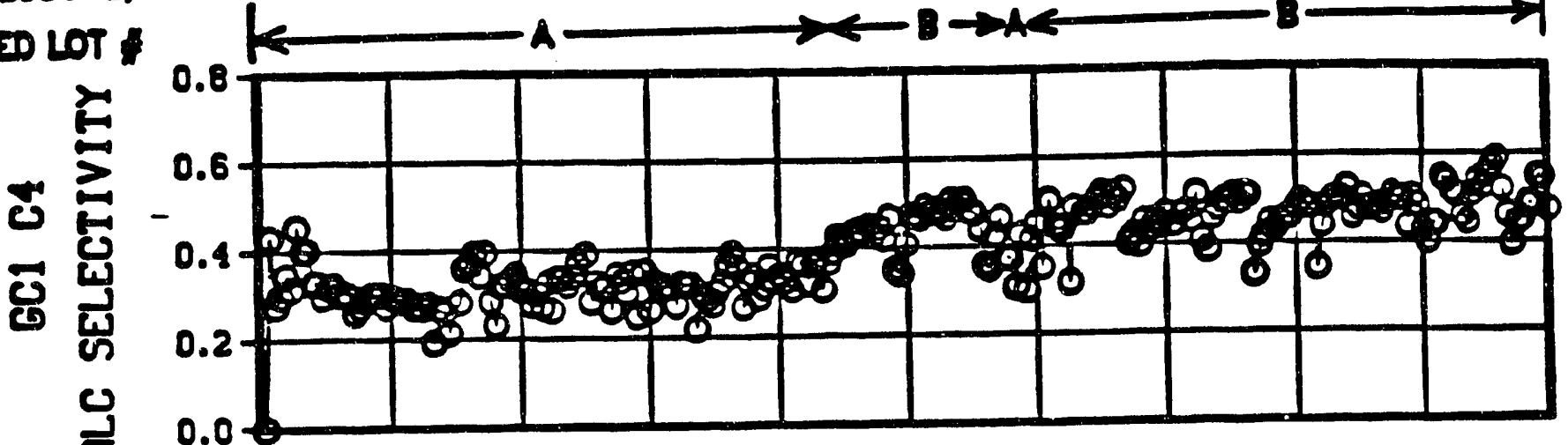

군

๘

0.6

0.1 -

क

0.0

0.2

8

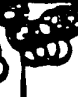

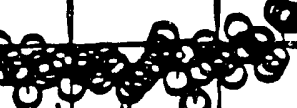

265
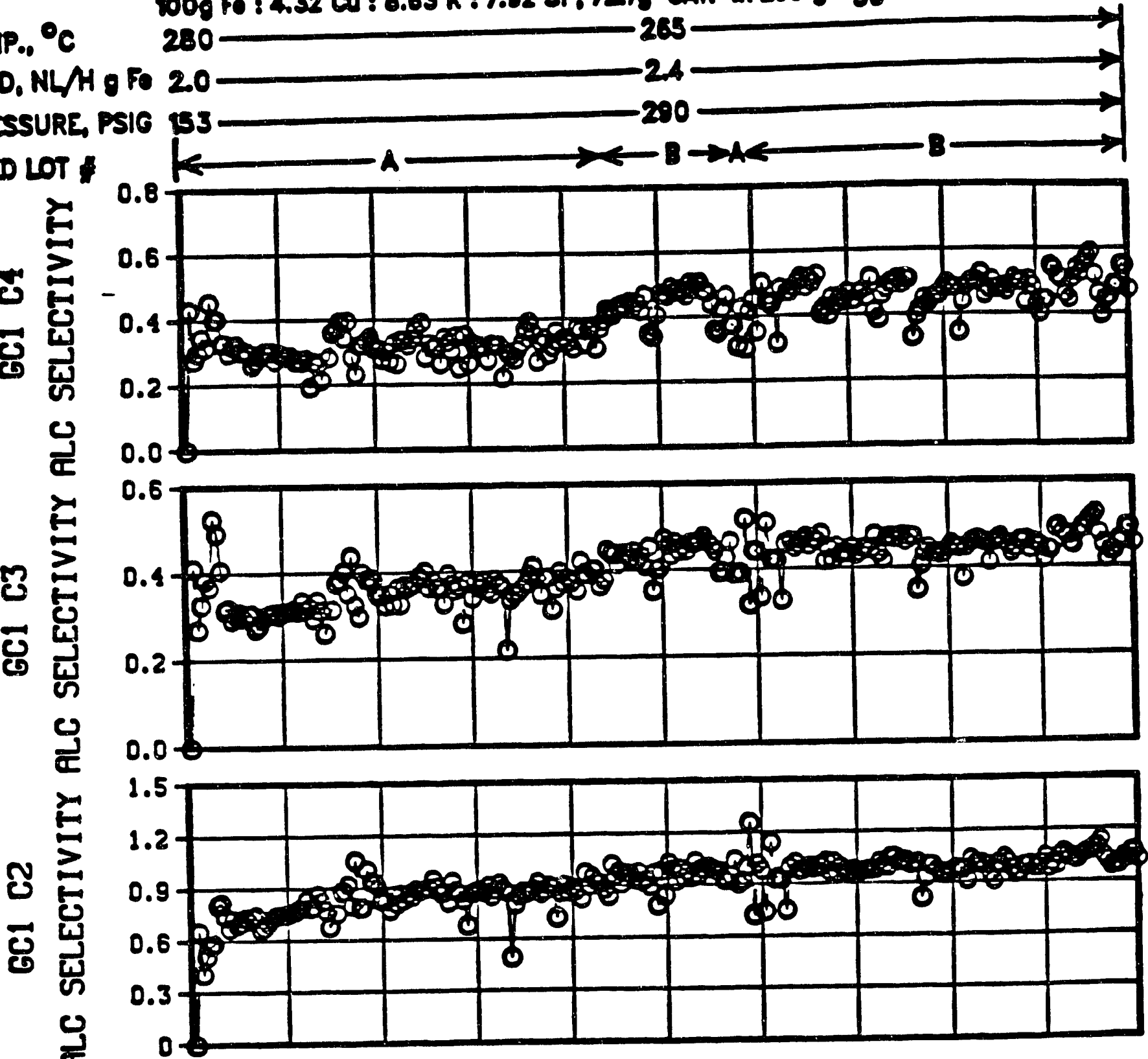

를

(1)

12

0
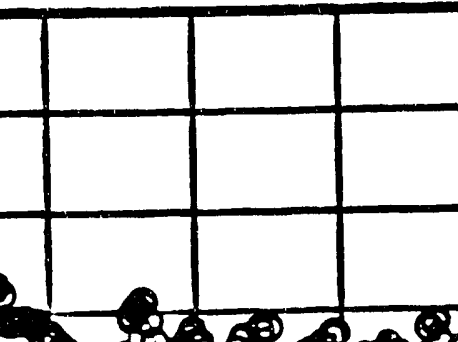
Pigure 13

UCI CATALYST

PLT 700B RUN $44 \mathrm{H}_{2}: \mathrm{CO}$ food $=0.7,1100 \mathrm{rpm}$ $100 \mathrm{~g}$ Fo : 4.32 Cu : $8.63 \mathrm{~K}: 7.02 \mathrm{S1}$ : 72.79 CAT. In 200 o $\mathrm{C}_{30}$ oll

TEMP.0 ${ }^{\circ} \mathrm{C} \quad 280$

FIDD, NL/H O FO 20

PRESSURE, PSIG 253

FED LOT

ठु

总

로

ปิ

K

$A \longrightarrow-B \rightarrow A$<smiles>[10BH]</smiles>
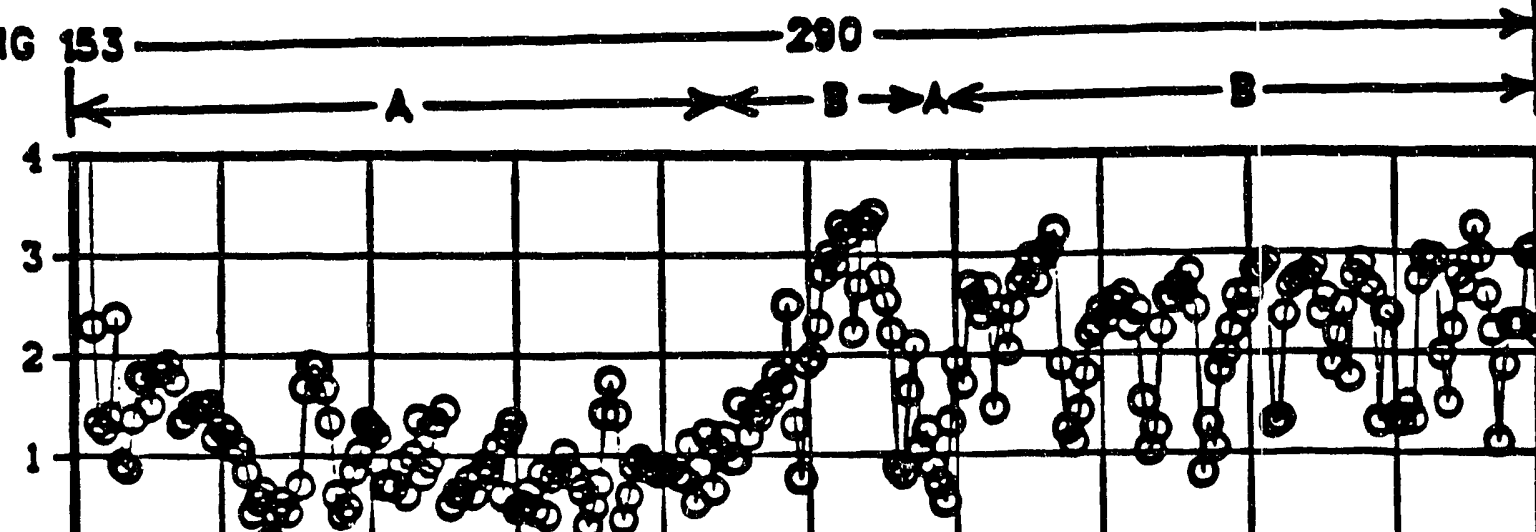

0
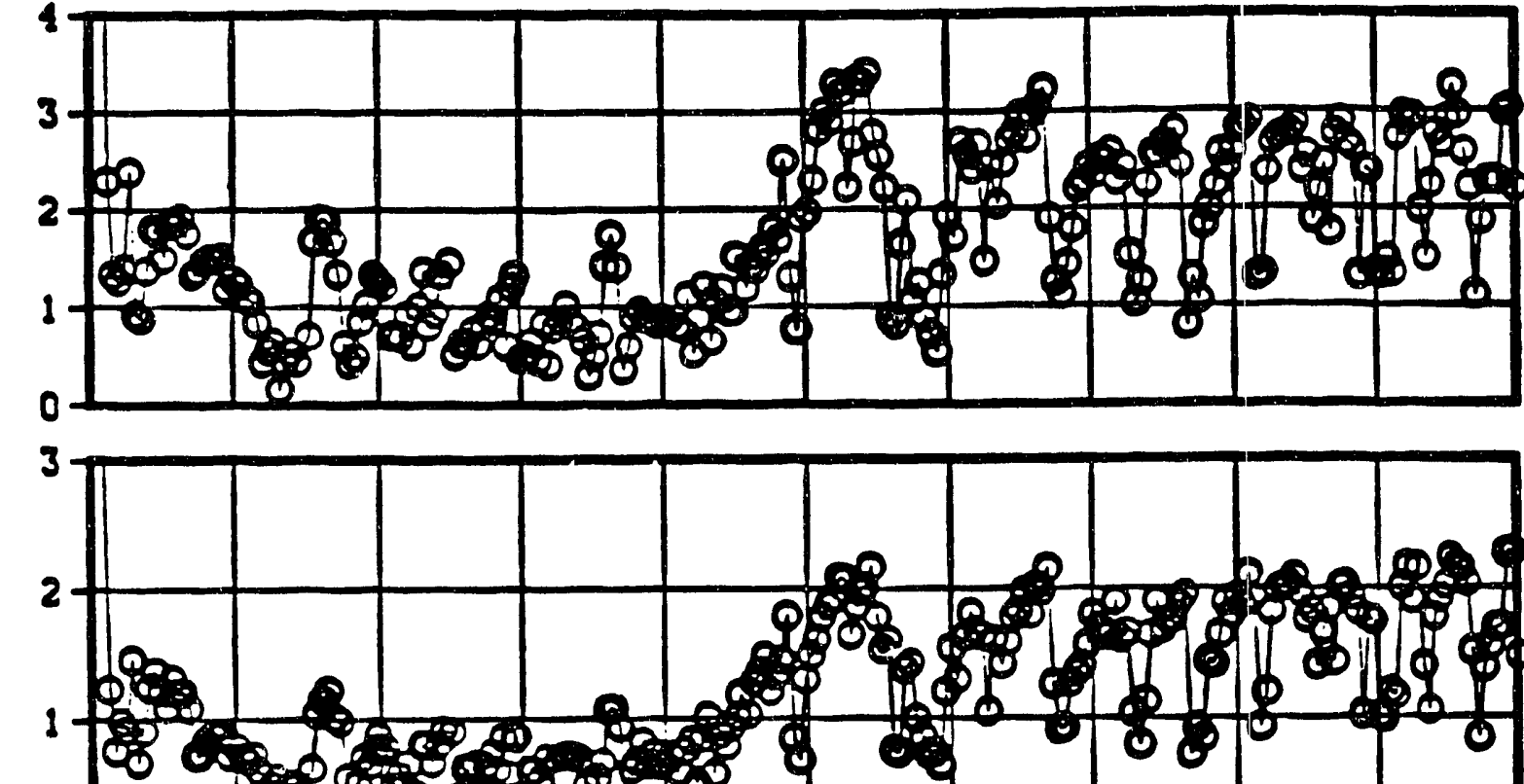

굴

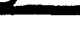
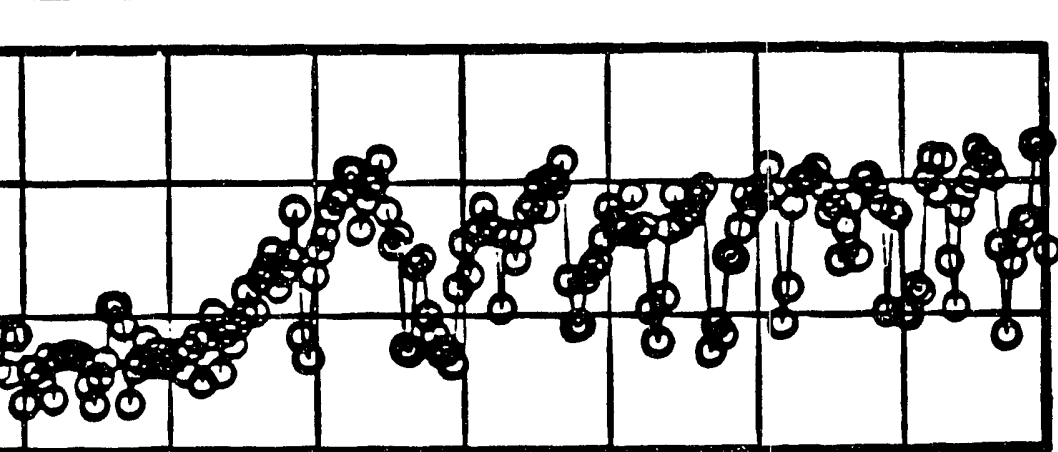

Ð

2

2

\& 80000000

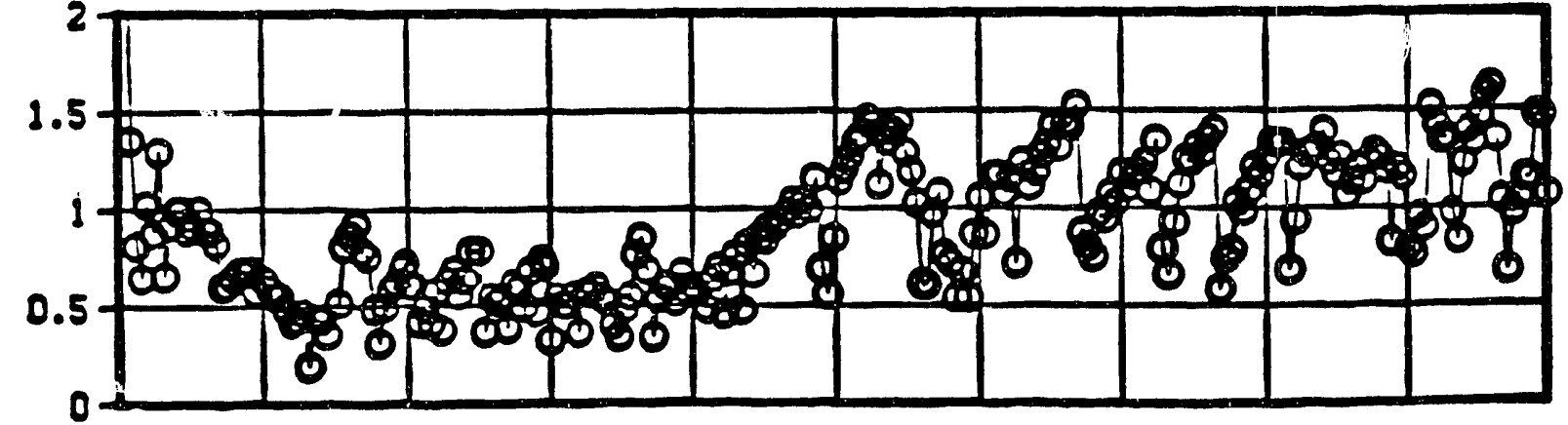

a.

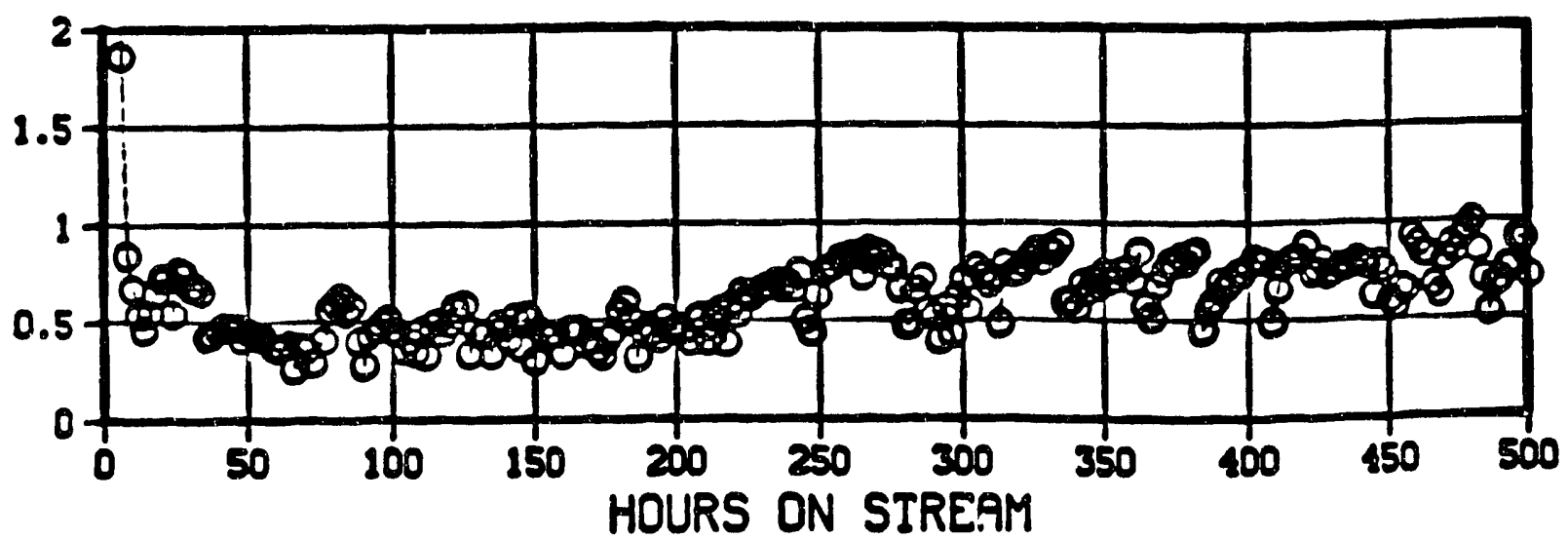




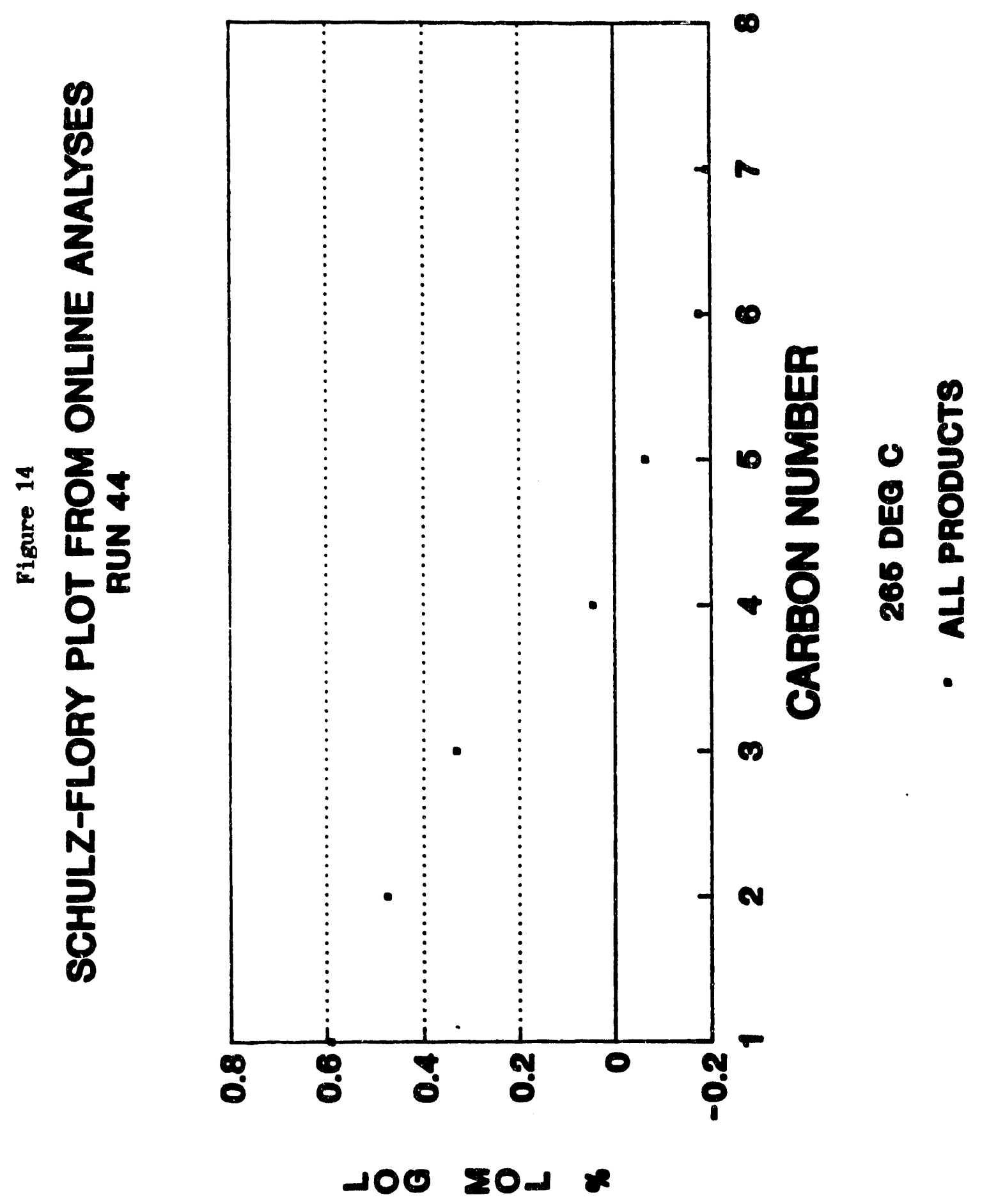




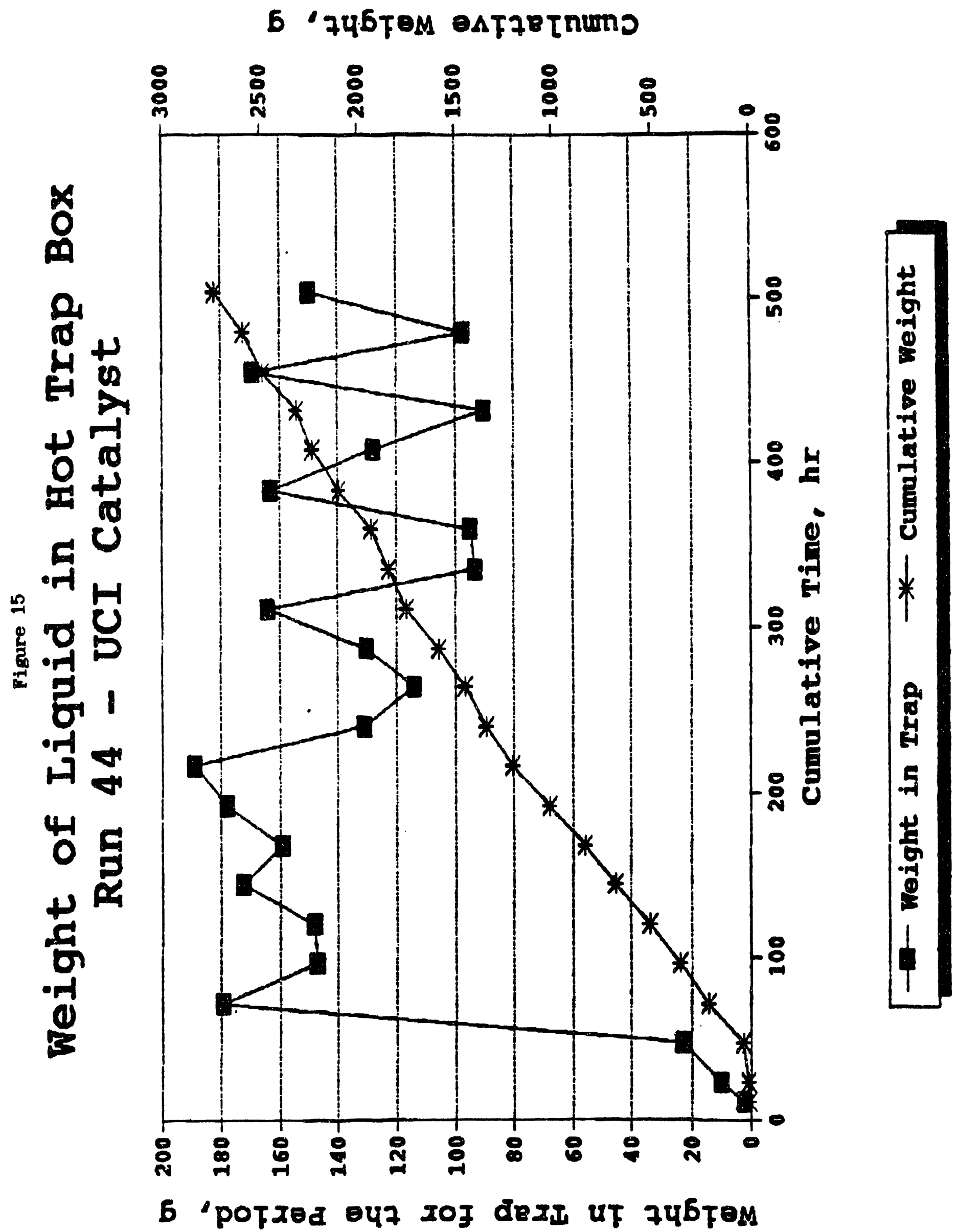




\section{Figure 16 \\ LQUID LEVEL Vs. HOURS ON STREAM PLANT 700B RUN 44}

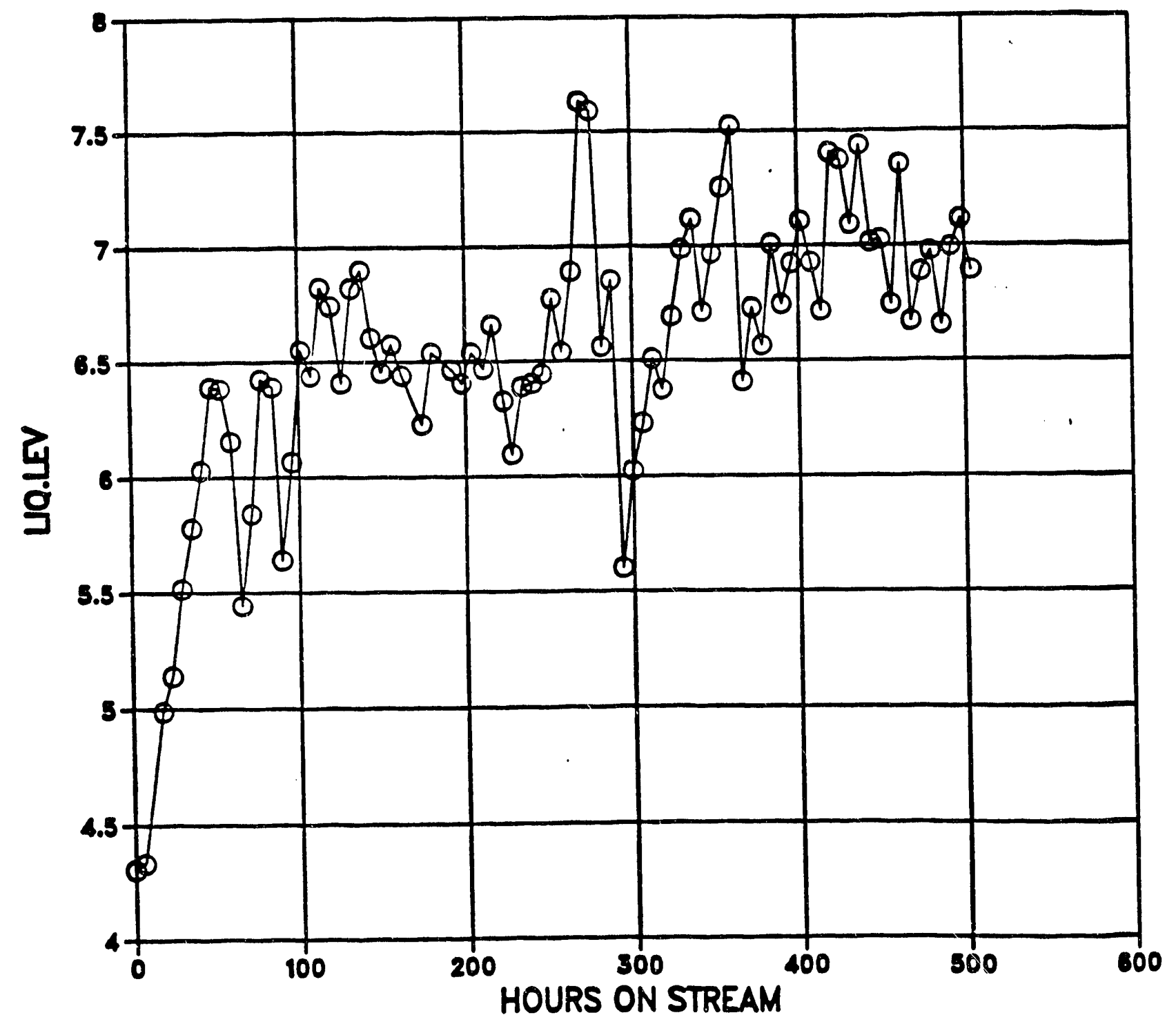


APPENDIX A

Summary Report of Al Van TII ca Oxalate Route

to Fischer-Tropech Catalysts 
Date: 1 MaY 92

From: Alan 2 . van T12

To: Ceorge J. Antos

Bubject: Flscher-Tropech (10158-0069), 8

$A$ vecuum gox we sun on the $K, C u, F e$ oxalate ande enrlier. M2 BET date was also obtalnod on the came anterlal after varlous

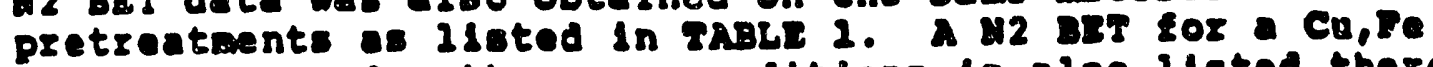
oxalate run under the can conditions 18 aloo listed there. The combinod BET E TGA data is show in Figure 1 . There, we see an Inttlal 1088 of surface bolsture, then a charp ase loss due to the two weters of hydration being abstracted at elightly bove 100 C. In contrast to any oxalates containing divalent lons such as $\mathrm{Mg}$, lron oxalate decomposes at a lower temperature, less than $400^{-C}$ by two cteps, and goes all the way to the aetal in vacuum rather etopping at the oxide. The mass lose after water abstraction up to ge. 200 c would flt with Co 2088 to wake carbonate. However, I w121 lmadiatoly add that the the sure asslgnment would ither cowe by adding a QPMs to look for co and $\mathrm{CO}_{2}$ during a TGA $r$ un or take a sample up to that atage and have an XRD analys 1 s done. The last Einal ans 108 say be a complex one whose implistic assignment would be Co+COe removel to form wetal. The final ass losses for the surface area masurements samples are given in rabe 1 . That we have the setal is conElrmed by the pyrophorlc behavlour of everal samples when contacted with alr at the end of the run. Because wo have an oxalate that decomposes by two steps openo the posiblilty of elrst vecuum calcining it up to 200 - C to remove Hzo and partially decompose 'she oxalate to open lts pore structure and then finish the job in alr to obtain a high ourface oxlde. That this approach 18 feasible is upported by two ltems. Flrst, the mase loss data 1 leted in rABLE 1 for the 175 oc treated semple and, cecond, the mid polnt mass 108 s temperatures of the transitions in FIGURE 1 are Ca. 175 C apart. From the work done so far using only vacuum caleination, we can obtain Fe wetal alther doped or surface covered with Cu $K$ having a surface area of nominaliy 60-75 $\mathrm{m}^{2} / 9$ when the oxalate 18 heated at 300-325 oc cor 40-64 hours. By being able to calcine the wateriel in alr for the second etage, we would avold the problem of having to CAREFULLY adding low os containing $H_{2}$ at the end of the vacuum calcination to pasadvete the Fe vetal surkace.

Next, I plan to try an experiment in the Mottler ros in which a saple is indtialiy vacuum celolned to $\mathrm{ge} .200 \circ \mathrm{C}$, then calcined to al. $100^{\circ} \mathrm{C}$ In $\mathrm{diz}$ and then checked as to Ito B.T surface area. Also, somewhat larger sample wlil be calcined In a separate vacuum systom tor XRD as part of scaling up the preparation of a suffelent materlal for a pllot plant run. Arrangements are in progress to obtain clearance from the safety Department for using co in carblding experiments scheduled in the Mettler TA-2 Thermalanalyzer eystem of varlous P-T catalysts. A CO mondtor mast be bought and instalied in B-2-R-156 before clearance can be granted. (NIVT) 
Table 1

Surface Area of Vacuum Calcined Fe Oxalates

\begin{tabular}{|c|c|c|c|c|c|c|c|}
\hline$S \#$ & $\begin{array}{c}{[\mathrm{K}],[\mathrm{Cu}],} \\
{[\mathrm{Fe}]}\end{array}$ & Temp, ${ }^{\circ} \mathrm{C}$ & Time, $\mathrm{hr}$ & $\begin{array}{c}\% \text { Mass } \\
\text { Loss }\end{array}$ & S.A. $\left(\mathrm{m}^{2} / \mathrm{g}\right)$ & P.V., cc/g & $\mathrm{m}$ PD, A \\
\hline $6753-27$ & $\mathrm{~K}=0$ & $300-325$ & 40 & 68.18 & 61.4 & 0.028 & 8.7 \\
\hline $6753-33$ & $\begin{array}{c}0.75, \\
4.16,100\end{array}$ & 25 & & 12.4 & 1.5 & & \\
\hline-33 & SAME & 175 & 3 & 30.1 & 44 & 0.019 & 7.7 \\
\hline-33 & SAME & 300 & 20 & 70.09 & 63.5 & 0.028 & 7.9 \\
\hline-33 & same & 300 & 64 & 71.28 & 73.9 & 0.037 & 10.9 \\
\hline .33 & same & 350 & 5 & 67.38 & 37.2 & 0.016 & 7.4 \\
\hline-33 & same & 350 & 16 & 68.30 & 42.6 & 0.020 & 9.5 \\
\hline
\end{tabular}




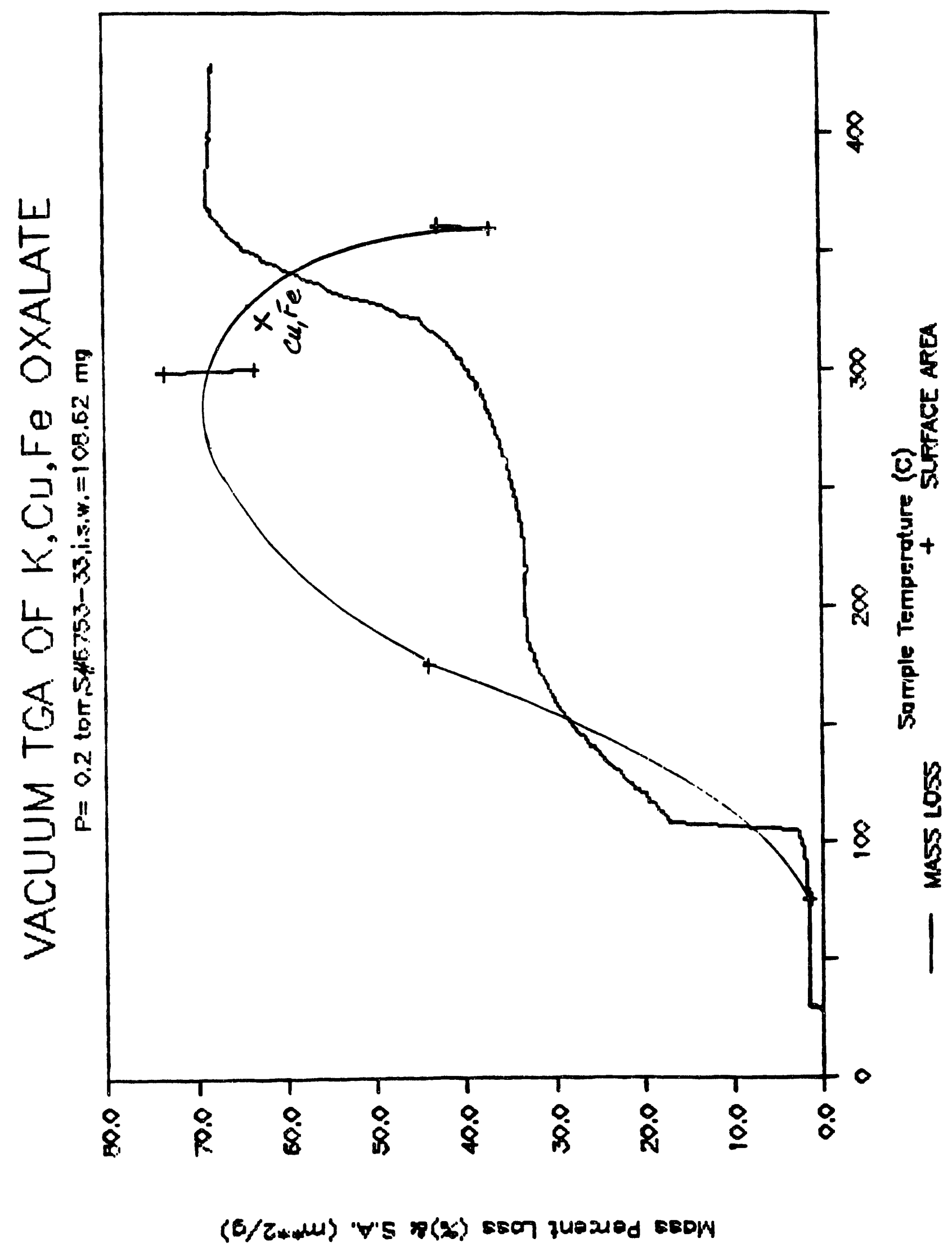




\section{APPENDIX B}

Summary of Phat $700 B, \operatorname{Rnn} 4$ 
Table 1

\section{Analysis of Feeds Run 44 (UCl Catalyst)}

\begin{tabular}{|l|c|c|}
\hline Component & Feed A & Feed B \\
\hline Co, mole $\%$ & 56 & 56 \\
\hline $\mathrm{H}_{2}$, mole $\%$ & 37 & 37 \\
\hline $\mathrm{A}$, mole $\%$ & 6 & 6 \\
\hline $\mathrm{N}_{2}$, mole $\%$ & 0.17 & 0.32 \\
\hline Total S, wppm & $<1$ & $<1$ \\
\hline $0_{2}$, WPPM & $<50$ & $<50$ \\
\hline
\end{tabular}

UOP

$3 / 19-20 / 1992$ 
Table 2

FISCHER-TROPSCH IRON CATALYST PROJECT

PLANI 70OB TRAP PRODUCT LOG

Run 44 U.C.I catalyst

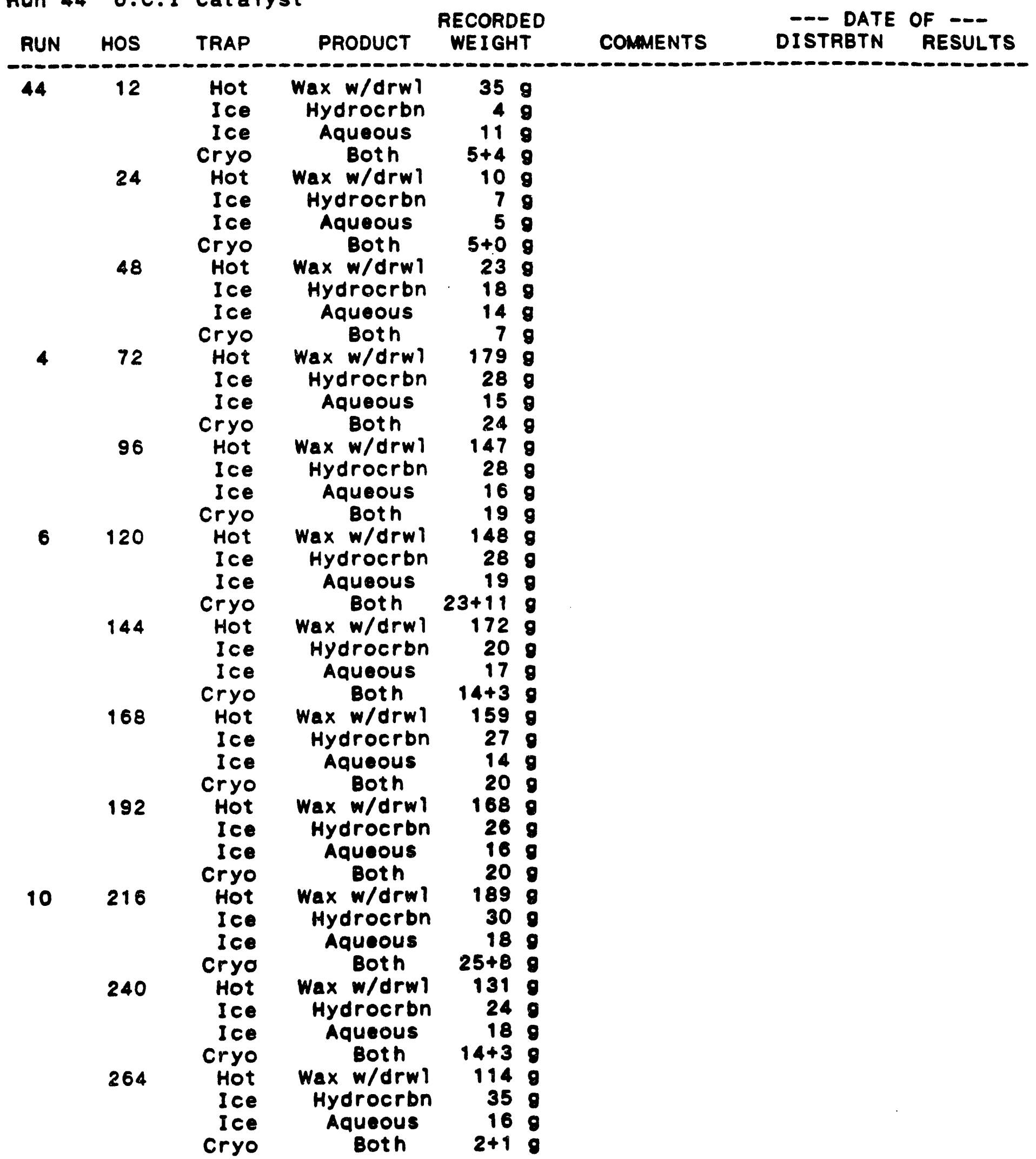


Table 2 (Cont)

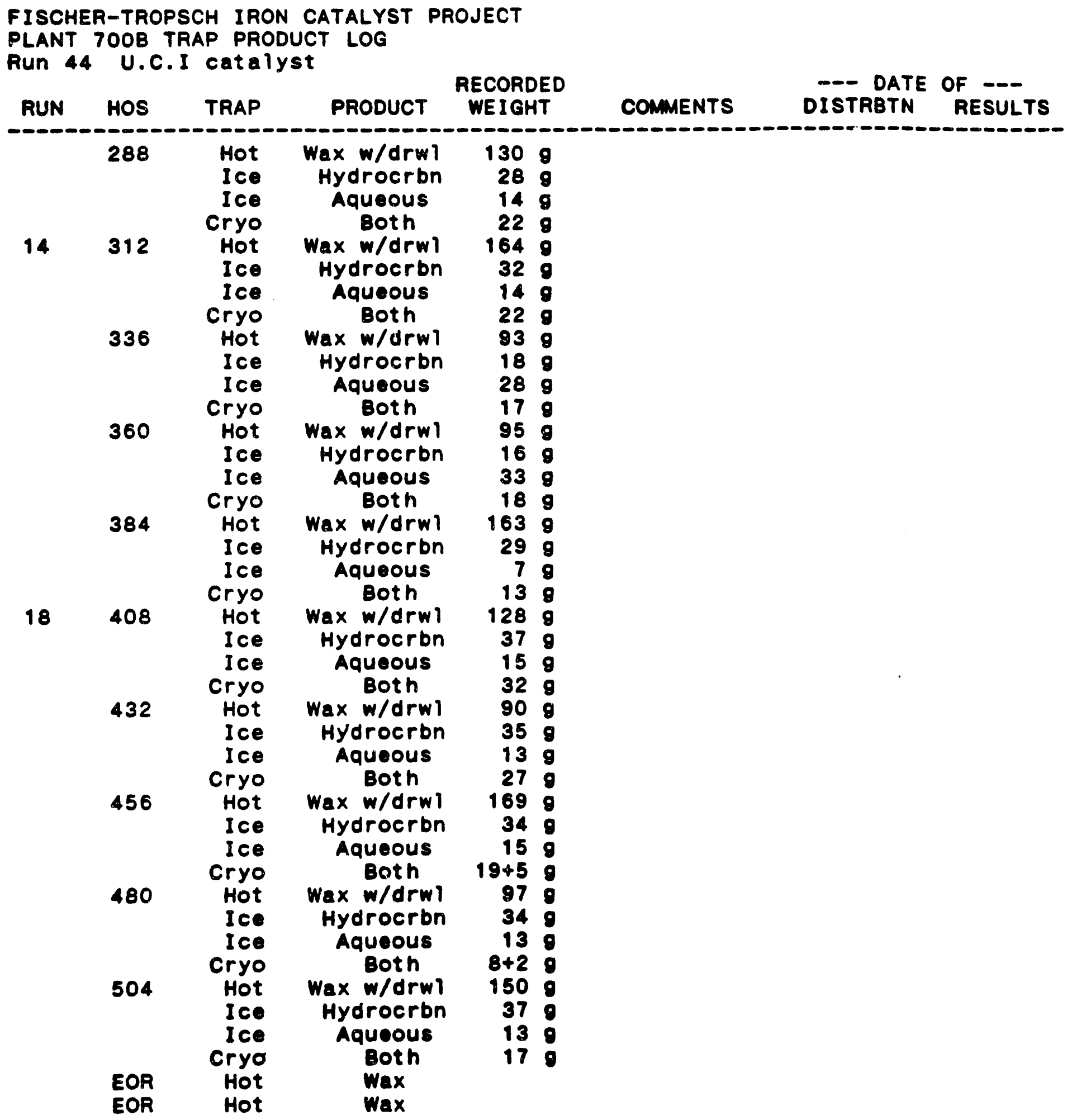



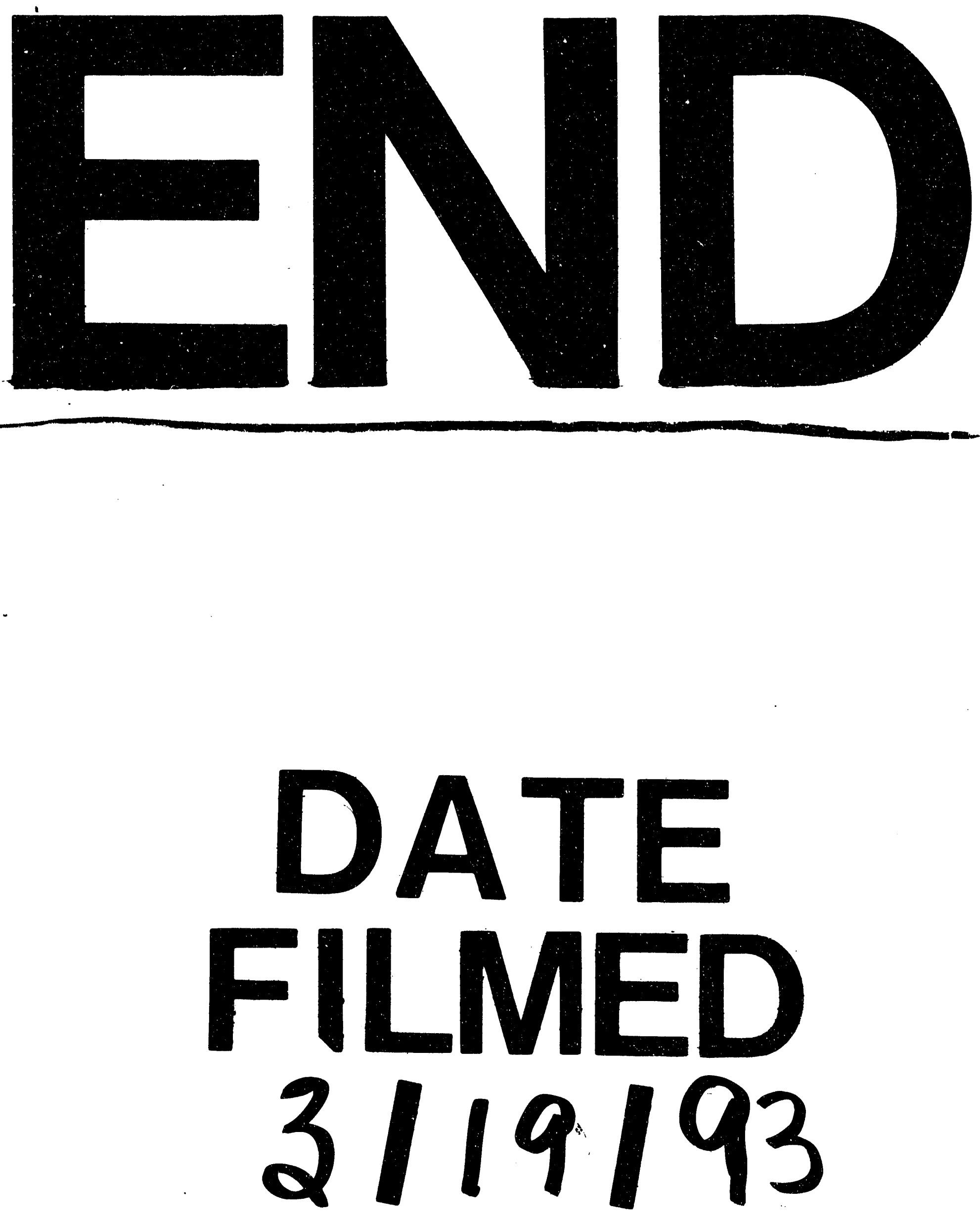
